\title{
Globuligerina oxfordiana (Grigelis, 1958) - revision of the first planktonic foraminifera discovered in the Upper Jurassic of Lithuania
}

\author{
Algimantas Grigelis \\ Institute of Geology and Geography, \\ Nature Research Centre, \\ Akademijos St. 2, Vilnius, Lithuania \\ E-mail algimantas.grigelis@geo.lt
}

Grigelis A. Globuligerina oxfordiana (Grigelis, 1958) - revision of the first planktonic foraminifera discovered in the Upper Jurassic of Lithuania. Geologija. Geografija. 2016. T. 2 (2). ISSN 2351-7549.

The article presents the self-revision and re-description of the first planktonic foraminifera Globuligerina oxfordiana (Grigelis, 1958) discovered in the Upper Jurassic of Lithuania. The original article published in 1958 in a Russian periodical (Moscow) is translated, supplied by additional comments, and illustrated by SEM laser electronic micrographs.

Key words: planktonic foraminifera, Jurassic, Globuligerinidae

\section{INTRODUCTION}

During two last decades, a few publications discussed early evolution and palaeobiogeography of Mesozoic planktonic foraminifera (Boudagher-Fadel et al., 1997; Gradstein, 1998; Hart et al., 2002; Hart et al., 2007). In 2009, it was noted that "over the last 50 years, our knowledge of early planktonic foraminifera has changed markedly. In 1958 Grigelis described "Globigerina oxfordiana" from the Upper Jurassic of Lithuania and this has, subsequently, become identified as one of the most geographically widespread of Jurassic planktonic taxa" (Hudson et al., 2009). Having in mind a great interest in this and related species, the author decided to make a revision and re-description of Globuligerina oxfordiana, actually after long years from its publication, now having a possibility to study the types of this species by a modern scanning microscopy technique.

\section{BASE DATA ON GLOBULIGERINA OXFORDIANA (GRIGELIS)}

The first discovery of planktonic foraminifera in the Upper Jurassic of Lithuania determined as
'Globigerina oxfordiana sp. n.' was published by A. Grigelis in 1958 in a rare Russian (Moscow) periodical (Grigelis, 1958, text-fig.); therefore, some years remain out of the eyes of western reader. However, in 1966 this species was found by J. Guyader in the Lower Oxfordian (Quenstedtoceras mariae Zone) of the Seine Basin (Guyader, 1966, Docteur Thèse). A short but concise description was done followed by a raw hand-drawn figure (op. cit., p. 178, Pl. 28, Fig. 28 a-c) (Fig. 1).

The same year, J. Guyader followed by G. Bignot published an article on Oxfordian planktonic foraminifera of Le Havre area (Seine-Maritime), Normandy (Bignot, Guyader, 1966). The authors described further genus Globigerina that in 1970 was changed by them to a new subgenus Globigerina (Globuligerina) (Bignot, Guyader, 1971), but gave extended data on the records of 'globigerina-like' foraminifera in Jurassic, else sometimes doubtful, since discovery of 'Globigerina liassina' by Terquem et Berthelin in 1875. A detailed description of Globigerina oxfordiana Grigelis, 1958 and comparison of the morphotypes with other known Jurassic globigerinae-species gives an impression on the identity of the taxa described, including similar dimensions of tests. The drawings 

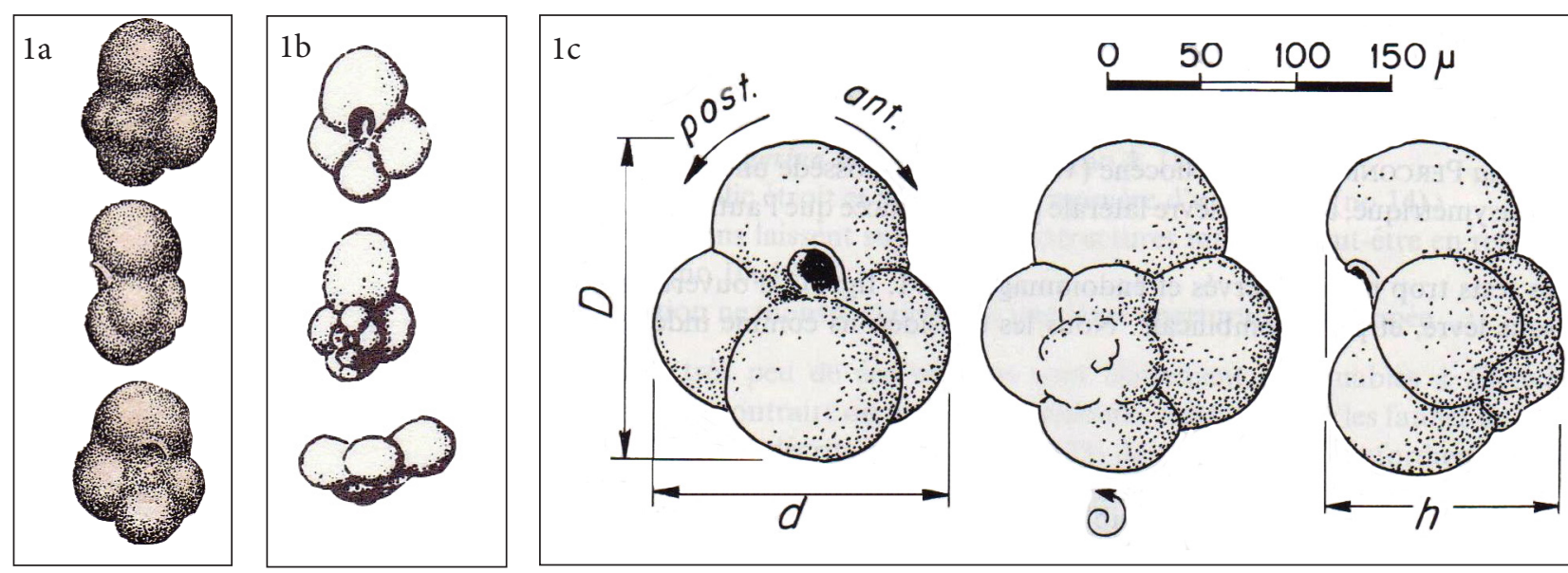

Fig. 1. First drawings of Globigerina oxfordiana Grigelis: 1a - after Grigelis, 1958, Lower Oxfordian, borehole Jotija, Lithuania, text-fig., p. 110 (orig. D - $200 \mu \mathrm{m}$; d - $150 \mu \mathrm{m}$; H - $130 \mu \mathrm{m}$; D:d - 1.33; d:H - 1.15) ${ }^{1}$; 1b - after Guyader, 1966, Lower Oxfordian, Argiles de Villers, p. 178, Pl. 28, Fig. 28 a-c; 1c - ideal view and biometric dimensions; after Wernli, 1986, p. 141, Fig. 3. Viewing dorsal side all specimens have a sinistral coiling

of Grigelis' holotype (Pl. 1, Fig. 1) and Le Havre original specimens (Figs. 3-6) show a good agreement with test shape, spiral coiling formula $(4+4)$, chambers and sutures view, aperture form and position (Fig. 2). The internal structure of Le Havre specimen shows a thin radially perforate wall.

Continuing their study, Bignot and Guyader in 1970, at the Second Planktonic Conference in Rome, reported on new observations of Globigerina oxfordiana Grigelis (Bignot, Guyader, 1971).

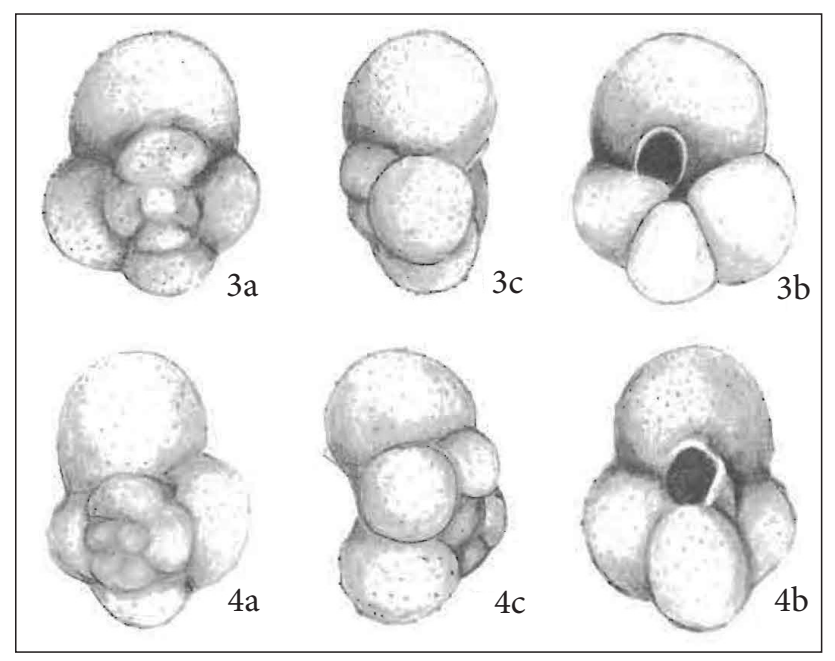

Fig. 2. Globigerina oxfordiana Grigelis, after Bignot et Guyader, 1966, p. 105-107, Pl. 1, Figs. 3-4; Lower Oxfordian, Avant-Port du Havre (orig. D - 3a - $140 \mu \mathrm{m}$, $4 \mathrm{a}-150 \mu \mathrm{m})$

1 Used dimensions: $\mathrm{D}$ - long axis, $\mathrm{d}$ - short axis, $\mathrm{H}$ - spiral height; D:d - test roundness index; $\mathrm{d}: \mathrm{H}$ - test flatness index.
Based on comparative analysis of type genus Globigerina bulloides d'Orbigny and Lithuanian and French material on Globigerina oxfordiana Grigelis, the authors established new subgenus Globuligerina under genus Globigerina, 'characterised by a virguline aperture, not perfectly umbilical, and with little lip' (op. cit., p. 79). In systematic description, the type-species Globigerina oxfordiana Grigelis, 1956 [should be 1958] emend. Bignot et Guyader, 1970, is named for the new subgenus
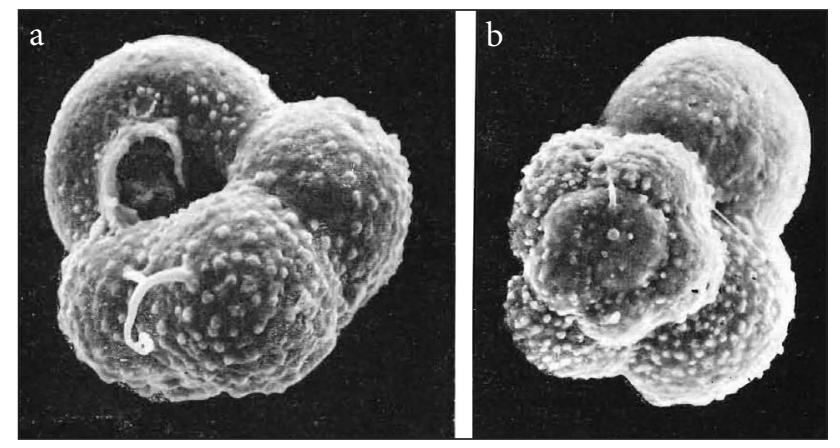

Fig. 3. Globigerina oxfordiana Grigelis: a - ventral side (orig. D - $120 \mu \mathrm{m}$ ); b - dorsal side (orig. D - $166 \mu \mathrm{m}$ ); Avant-Port du Havre; after Bignot et Guyader, 1971, p. 83, Pl. 1, Figs. 1-2

Globuligerina. The authors first used the scanning electron microscope JEOL JSM2 for Jurassic planktonic foraminifera, very helpful for a detailed survey of wall structure, perforation and surface (Fig. 3). 
Thus, after the first publications the knowledge of Globuligerina oxfordiana (Grigelis) was considerably enlarged in 1980-1990s, some studies used advanced new SEM data. In 1980, A. Grigelis and T. Gorbachik published a detailed study of the morphology and taxonomy of Favusellidae species from the Middle Jurassic to Cenomanian based on SEM data, discussing the development of its sculpture and porosity (Grigelis, Gorbatchik, 1980a, 1980b). The latter article presents for the first time for western readers the extended data on several species of the Jurassic and Early Cretaceous planktonic foraminifera based on a detailed study of its morphology of tests with a scanning electron microscope (in Moscow University). The topotype of Globuligerina oxfordiana (Grigelis) indicates the primary porosity of $0.4-0.5 \mu \mathrm{m}$ and pustulose test surface forming irregular or more or less quadrangular cells ("muricae" surface). Family Favusellidae Longoria, 1974 includes genera Conoglobigerina Morozova, 1961, Globuligerina Bignot et Guyader, 1971, and Favusella Michael, 1972 that is characterised by 'tubercular or reticulate sculpture of the test surface and an umbilical position of the aperture' (Grigelis, Gorbatchik, 1980b, p. 180). This family includes more than 30 species characterised by an extensive geographic distribution in Tethyan realm and its northern Perithetys margins. Later on, T. N. Gorbachik published a special study on the wall structure of Globuligerina oxfordiana (Grigelis) showing on SEM pictures the densely pustulose wall sculptured by thick cones or short ridges and the radially crystalline calcite wall with $1 \mu \mathrm{m}$ microcrystal plates isolated by an organic membrane (Gorbachik, 1983). Just a year later, Loeblich and Tappan (1984) introduced a new family Globuligerinidae, especially collecting Jurassic globigerina-like foraminifera.

Continuously working on Lithuanian materials, in 1985 the author published a monograph on the Jurassic foraminifera of the south-west Baltic area describing the systematic and taxonomy of abundant foraminifera assemblages from the Bathonian to the Lower Volgian (Tithonian). Taxa description contains 231 species; moreover, 53 new species, 4 new genera and 2 new subfamilies are established; light microscope foraminifera photos are compiled in 40 palaeontological plates. As regards Jurassic planktonic foraminifera, a de- tailed description of genus Globuligerina Bignot et Guyader, 1971 is given, first applying the ratio D:d and $\mathrm{d}: \mathrm{H}$ ratio for shell characteristics (Grigelis, 1985a); also the holotypes of Globuligerina oxfordiana (Grigelis) (Fig. 4) and Globuligerina stellapolaris Grigelis are newly re-drawn. Published in Russian, this monograph is rarely in use by western readers. In 1985 again, the author published another paper on zone stratigraphy of the Baltic Jurassic according to foraminifers (Grigelis, 1985b) presenting the original methodology of analysis of foraminifera zones setting up stratigraphic subdivision of the Upper Bathonian to the Lower Volgian (Tithonian) based on the foraminifera zone assemblages.

In 1986, an extended decadal field survey of ammonites and foraminifers of the Upper Jurassic in Central Russia (Kostroma and Rjasan' districts) was a result of collective work (Azbel et al., 1986). The discovery of abundant and very well preserved Globuligerina oxfordiana (Grigelis) made in Shatrishche in 1977 was repeated in the sections of Makarievo on the Unzha River, supplying later researchers with excellent material for the SEM studies (e. g. Gorbatchik, 1983; Gorbachik, Kuznetsova, 1997).

Later on, in 1996, K. I. Kuznetsova, A. A. Grigelis, J. Adjamian, E. Jarmakani and L. Hallaq published a monograph on zone stratigraphy and foraminifera of the Tethyan Jurassic (Eastern Mediterranean) (Kuznetsova et al., 1996) establishing a zone subdivision for Syrian Jurassic within the Lias-Tithonian stratigraphy interval based on the evolution of the foraminifera assemblages. During field work in Syria, in 1986-1989 (Grigelis et al., 1989), despite large benthic foraminifers prevailing in limestone lithofacies [carbonate platform], a large amount of small lenticulinid-epistominid type species was determined in the soft clayey intercalations. The single specimens of Globuligerina bathoniana (Pazdro) in the Bathonian and Globuligerina oxfordiana (Grigelis) (Fig. 5) in the Lower Oxfordian of several Syrian localities were found, described and depicted by light microscope photos. The exposed G. bathoniana is bigger $(\mathrm{D} 460 \mu \mathrm{m})$ than G. oxfordiana (D 300$360 \mu \mathrm{m})$.

As a result of a Lithuanian-Swedish geotraverse study on the Jurassic geology and foraminifera faunas in the NW part of the East European 


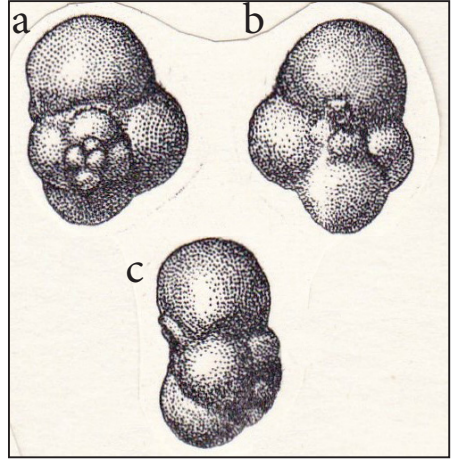

Fig. 4. Globuligerina oxfordiana (Grigelis, 1958). Holotype re-drawn by $S$. Nikolayev, S. Ptsb., in 1980: a - dorsal view; b - ventral view; c - peripheral view. Jotija borehole, $143 \mathrm{~m}$, sample 10. Lower Oxfordian, SW Lithuania. After Grigelis, 1985, pl. VIII, fig. 6a-c; × 102 (orig. D - $200 \mu \mathrm{m}$ )

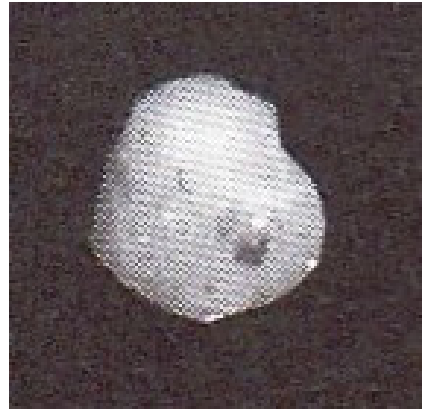

Fig. 5. Globuligerina oxfordiana (Grigelis, 1958). Original, light microscope photo, dorsal view, sample 733, Palmyrides, exposure As-Sattieh, Wadi Hayan, Syria, Lower Oxfordian. After Kuznetsova, Grigelis et al., 1996, p. 191, Pl. XV, Fig. 24 (orig. D - ca. $300 \mu \mathrm{m}$ )

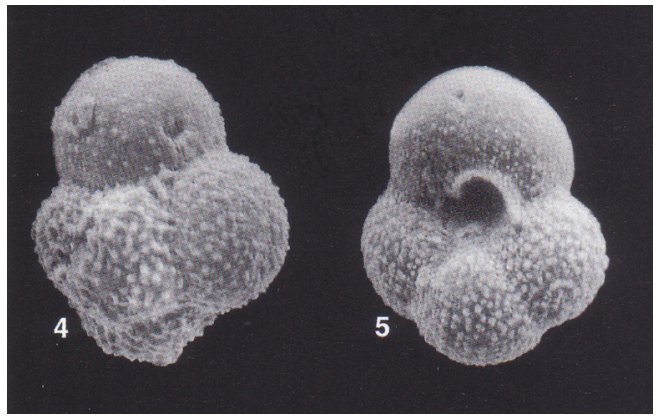

Fig. 6. Globuligerina oxfordiana (Grigelis, 1958). 4. Topotype, dorsal view, Jotija borehole, $143 \mathrm{~m}$, sample 10. Lower Oxfordian, SW Lithuania, AG SEM 522, Palaeozoology Institute, Stockholm, $\times$ 250. 5. Paratype, ventral view. Shatrishche-2, sample 801. Middle to Upper Oxfordian, Rjasan', Central Russia. AG SEM 523, Palaeozoology Institute, Stockholm, $\times 250$. After Grigelis and Norling, 1999, Plate 5, Figs. 4, 5, p. 86
Platform, in 1999 A. Grigelis and E. Norling displayed the new SEM photos of selected Jurassic species, including Globuligerina oxfordiana (Grigelis) from the Oxfordian of Jotija borehole ( $\mathrm{Li}$ thuania), Shatrishche-2 section (Rjasan', Central Russia) (Fig. 6), and Hano Bay borehole (Sweden, Eastern Scania) (Grigelis, Norling, 1999, 2000).

\section{GEOLOGICAL SETTING}

Geological development of Lithuania is determined by large tectonic structures, Baltic Syneclise, Masurian-Belarussian Anteclise, and Latvian Saddle, belonging to the Precambrian East European Craton (Fig. 7). The lower structural stage of geological sequence consists of the Proterozoic crystalline rocks of the pre-Riphean occurring at the depths of 200-2,300 m below NN, and the upper one is composed of sedimentary rocks from the Ediacaran (Vendian) age and to the Quaternary (Grigelis, Kadūnas, 1994; Baltrūnas et al., 2004). From the tectonic point of view, the sedimentary cover, due to the character of geological formations, their genesis and presence of regional angular unconformities, is divided into structural complexes, stages and substages. The Alpine complex (Upper Permian-Quaternary) is characterised by a number of local tectonic structures affected by faults and local monoclinal or semi-brachyanticlinal structures (Grigelis, in: Sigmond, 2002, 2007).

The Mesozoic section, in particular, is represented by Triassic, Jurassic and Cretaceous sedimentary rocks cropping out on the pre-Quaternary surface, thus shaping the Polish-Lithuanian Syneclise. As regards the Jurassic period, this inherited moist climate conditions after the end of the Triassic when the Rhaetian was formed by continent weathering products represented with light kaolinitic-hydromicaceous clays (up to 15 $\mathrm{m}$ thick). The Jurassic is distributed in the western-south-western part of Lithuania (see Fig. 7). The section is represented in the lower part by continental and brackish deposits of the Lower and Middle Jurassic and the Lower Callovian, while the upper part is set by the Upper Jurassic marine deposits from the Middle Callovian to the Oxfordian, Kimmeridgian, and Tithonian (Volgian) (Grigelis, in: Sigmond, 2002). The total thickness is $20-30 \mathrm{~m}$ in the north-east of the basin and up to $240-250 \mathrm{~m}$ in its southwest, on the boundary with Poland. Along the banks of the Venta River, the Jurassic deposits appear on the land surface in the Papile settlement environs. South-westwards, the Jurassic layers lie under younger Cretaceous deposits, at the depths from $60-150$ to $300-320 \mathrm{~m}$ below $\mathrm{NN}$, where more complete sections are found. The whole Jurassic 


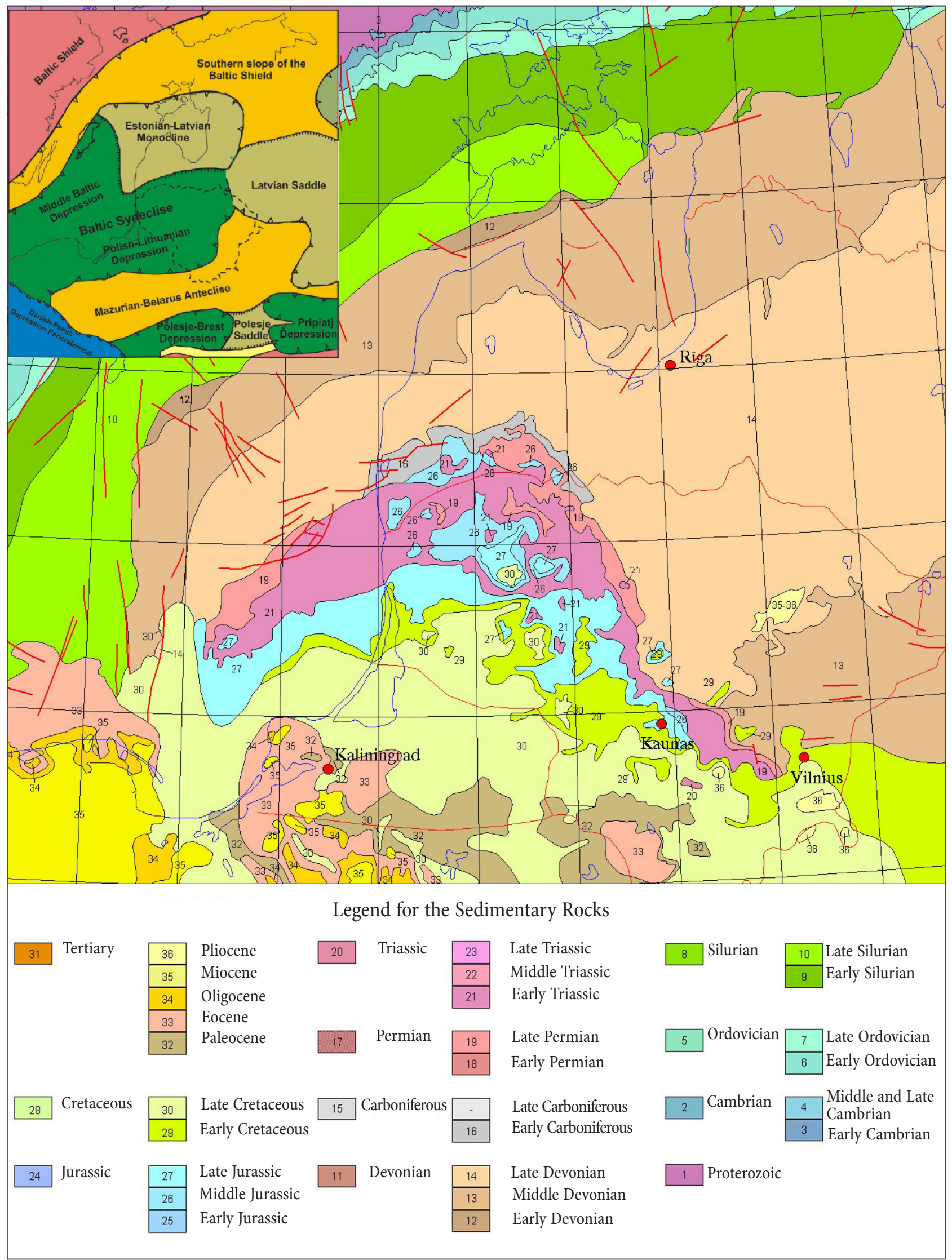

Fig. 7. Basical geological map of the Baltic region; distribution of Mesozoic sedimentary rocks from Upper Permian to Cretaceous outlines contours of Polish-Lithuanian Syneklise, after A. Grigelis, 2011. Inset: Main tectonic structures of the Baltic region, after P. Suveizdis, 2003 
section is subdivided into regional formations, and marine deposits also to ammonite and foraminifera zones (Grigelis, 1985b; Rotkytè, 1987).

As to palaeogeography, in the Early and Middle Jurassic the continental regime predominated, and the late Triassic break embraced the beginning of the Early Jurassic (Grigelis et al., 1992). The small continental shallow basins began to form in the late Pliensbachian and the Toarcian under the effect of slow tectonic descents, in which sandy-clayey sediments with traces of breaks and weathering were deposited. During the Bajocian and early Bathonian, in some intervals these sediments were overburdened by sandy-clayey deposits with floral remains, transformed later into brown coal or lignite. At the end of the Middle Jurassic, during the late Bathonian and early Callovian, the first signs of transgression appeared, resulting in marine ingressive intercalations of sandy-clayey sequence with the foraminifera and bivalves. At the end of the Middle Jurassic (from the middle Callovian), almost the whole territory (with the exception of its north-eastern area) was embraced by a powerful transgression of the Central European marine basin, ensuing from the southwest. Palaeogeographic conditions underwent fundamental changes and a large Jurassic Baltic Basin was formed, in which during the whole late Jurassic epoch (25 Ma) sandy, clayey and carbonate sediments were deposited, and the varied Protozoa and Invertebrate fauna flourished. An extremely rich fauna indicates that the late Jurassic basin was of a low energy shelf type (up to 200-250 m deep) and of normal salinity; water was saturated with dissolved calcium carbonate. The climate was warmer than in the middle latitudes (Šimkevičius et al., 2003). The basin through the North German-Polish Sea communicated widely with the World Ocean. At the end of the Jurassic, the sea retreated from the territory of Lithuania.

\section{SITES DESCRIPTION}

The description of type localities of G. oxfordiana (Grigelis) given below is based on author's notes made during field work in Lithuania on these boreholes in 1956; additional comparative material was sampled in Central Russia at Nikitino environs in 1977 (Fig. 8). No special analyses of lithology content of sedimentary rocks were made. $\mathrm{Mi}$ crofauna remnants were picked up by the author after standard sediment disintegration and handsieving procedure. Foraminifera were found abundant (>100 specimens per $1 \mathrm{~g}$ of dry residual) in all samples studied.

Borehole Jotija No. 10, 1952, Šakiai District, Lithuania, depth $200.3 \mathrm{~m}$; NN $60.00 \mathrm{~m}$; coord. $55^{\circ} 02^{\prime} 17 \mathrm{~N}: 23^{\circ} 11^{\circ} 42 \mathrm{E}$ (Table 1; Fig. 9, right side).

Borehole Lyduvėnai, 1950, Raseiniai District, Lithuania, depth $101.25 \mathrm{~m}$; NN $70.00 \mathrm{~m}$; coord. $55^{\circ} 30^{\prime} 29 \mathrm{~N}: 23^{\circ} 04^{\prime} 59 \mathrm{E}$ (Table 2, Fig. 9, left side).

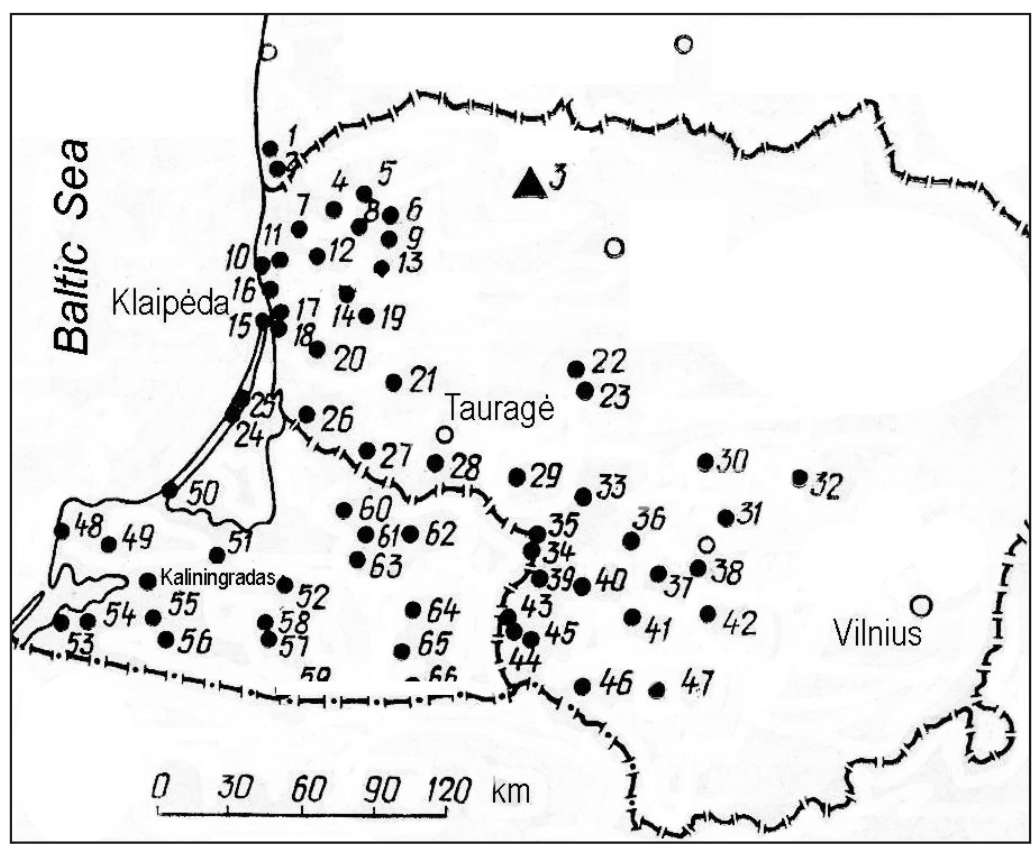

Fig. 8. Location map of studied sections mentioned in the text: 3 - Papile; 22 - Lyduvenai; 33 - Jotija. After A. Grigelis, 1985a, Fig. 3 


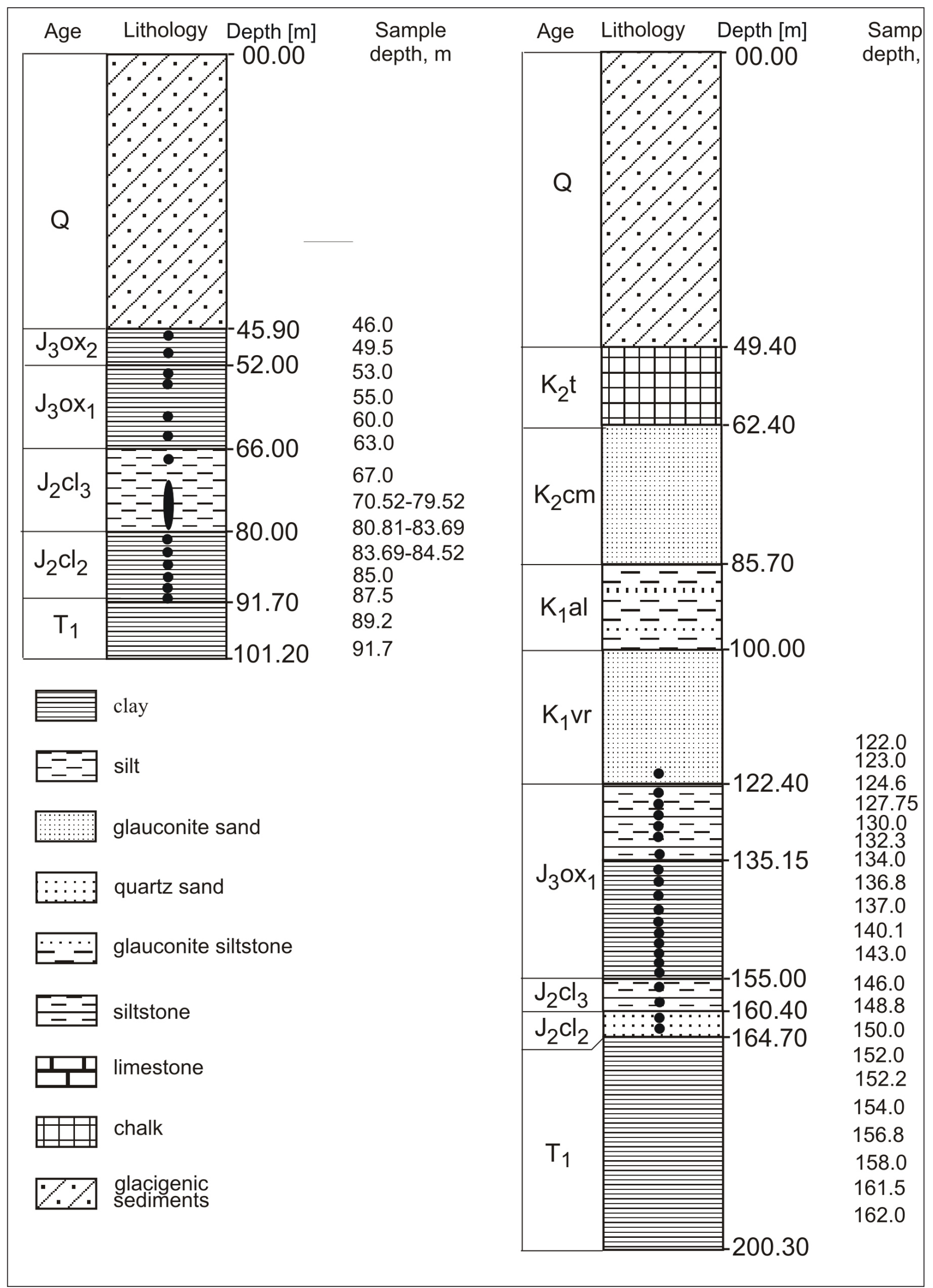

Fig. 9. Borehole logs of Lyduvènai (left) and Jotija (right); sampling points are marked by dots 
Table 1. Jotija borehole log description and Jurassic foraminifera assemblage based on $\mathbf{1 5}$ samples (at a depth of 123 to $158 \mathrm{~m}$ )

\begin{tabular}{|c|c|c|c|}
\hline Log description & Depth, m & Lithology & Foraminifera \\
\hline Quaternary & $0.00-49.4$ & & \\
\hline $\mathrm{K}_{2}$ Turonian & $49.4-62.4$ & Chalk greyish white & \\
\hline $\mathrm{K}_{2}$ Cenomanian & $62.4-85.7$ & $\begin{array}{l}\text { Glauconite sand } \\
\text { greyish green }\end{array}$ & \\
\hline $\mathrm{K}_{1}$ Albian & $85.7-100.0$ & $\begin{array}{c}\text { Glauconite siltstone } \\
\text { dark green }\end{array}$ & \\
\hline $\mathrm{K}_{1}$ Vraconian & $100.0-122.4$ & $\begin{array}{l}\text { Glauconite sand } \\
\text { dark green }\end{array}$ & \\
\hline $\begin{array}{l}\mathrm{J}_{3} \text { Lower } \\
\text { Oxfordian }\end{array}$ & $122.4-135.1$ & $\begin{array}{l}\text { Siltstone dark } \\
\text { greyish micaceous } \\
\text { calcareous }\end{array}$ & \multirow{2}{*}{$\begin{array}{l}\text { Globuligerina oxfordiana (Grigelis), Ophthalmidium stu- } \\
\text { ifense (Paalzow), O. birmenstorfense (Kuebler et Zwingli), } \\
\text { Lenticulina quenstedti (Guembel), L. brueckmanni (Mjat- } \\
\text { liuk), L. posttumida (Dain), L. comptula (Schwager), } \\
\text { L. subgaleata (Wisniowski), Planularia vaginuliniformis } \\
\text { (Paalzow), Spirillina tenuissima (Guembel), Trocholina } \\
\text { transversarii Paalzow, Pseudolamarckina jotijae Grigelis, } \\
\text { Paulina furssenkoi (Grigelis), Epistomina volgensis Mjat- } \\
\text { liuk, E. intermedia Mjatliuk, E. nemunensis Grigelis, E. uh- } \\
\text { ligi Mjatliuk, E. parastelligera (Hofker), Epistominoides } \\
\text { primaevus Grigelis }\end{array}$} \\
\hline $\begin{array}{l}\mathrm{J}_{3} \text { Lower } \\
\text { Oxfordian }\end{array}$ & $135.1-155.0$ & $\begin{array}{l}\text { Clay dark greyish } \\
\text { micaceous calcare- } \\
\text { ous }\end{array}$ & \\
\hline $\begin{array}{l}\mathrm{J}_{2} \text { Upper } \\
\text { Callovian }\end{array}$ & $155.0-160.4$ & $\begin{array}{l}\text { Siltstone greyish } \\
\text { black micaceous } \\
\text { calcareous piritized }\end{array}$ & $\begin{array}{l}\text { Ophthalmidium marginatum Wisniowski, Ichthyolaria } \\
\text { suprajurensis (Mjatliuk), Lenticulina spp., Planularia } \\
\text { dilatata Wisniowski, Pseudolamarckina jotijae Grigelis, } \\
\text { Epistomina mosquensis Uhlig, E. stelligeraeformis Mjatliuk }\end{array}$ \\
\hline $\begin{array}{l}\mathrm{J}_{2} \text { Middle } \\
\text { Callovian }\end{array}$ & $160.4-164.7$ & $\begin{array}{l}\text { On top } 0.3 \mathrm{~m} \text { grey } \\
\text { oolithic limestone, } \\
\text { below dark grey dif- } \\
\text { ferent quartz sand }\end{array}$ & No data \\
\hline $\mathrm{T}_{1}$ Lower Triassic & $164.7-200.3$ & Clay red coloured & \\
\hline
\end{tabular}

Table 2. Lyduvènai borehole log description and Jurassic foraminifera assemblage based on 7 samples (at a depth of 52.0 to $91.7 \mathrm{~m}$ )

\begin{tabular}{|c|c|c|c|}
\hline Log description & Depth, m & $\begin{array}{l}\text { Lithology, } \\
\text { macrofossil remnants }\end{array}$ & Foraminifera \\
\hline Quaternary & $0.0-45.9$ & & \\
\hline $\begin{array}{l}\mathrm{J}_{3} \text { Upper } \\
\text { Oxfordian }\end{array}$ & $45.9-52.0$ & $\begin{array}{l}\text { Clay dark greyish } \\
\text { micaceous calcareous }\end{array}$ & No sample \\
\hline $\begin{array}{l}\mathrm{J}_{3} \text { Lower } \\
\text { Oxfordian }\end{array}$ & $52.0-66.0$ & $\begin{array}{l}\text { Clay dark greyish mi- } \\
\text { caceous calcareous; } \\
\text { Cardioceras tenuicos- } \\
\text { tatum Nikitin, Cylin- } \\
\text { drotheutis beaumon- } \\
\text { tiana (Orbigny) }\end{array}$ & $\begin{array}{l}\text { Globuligerina oxfordiana (Grigelis), L. compressaeformis } \\
\text { (Paalzow), L. comptula (Schwager), Trocholina transver- } \\
\text { sarii Paalzow, Pseudolamarckina jotijae Grigelis, Paulina } \\
\text { furssenkoi (Grigelis), Epistomina volgensis Mjatliuk, E. in- } \\
\text { termedia Mjatliuk, E. uhligi Mjatliuk, E. stelligeraeformis } \\
\text { Mjatliuk }\end{array}$ \\
\hline $\begin{array}{l}\mathrm{J}_{2} \text { Upper } \\
\text { Callovian }\end{array}$ & $66.0-80.0$ & Silt greyish & $\begin{array}{l}\text { Lenticulina spp., Epistomina volgensis Mjatliuk, E. interme- } \\
\text { dia Mjatliuk, E. uhligi Mjatliuk, E. stelligeraeformis Mjatliuk }\end{array}$ \\
\hline $\begin{array}{l}\mathrm{J}_{2} \text { Middle } \\
\text { Callovian }\end{array}$ & $80.0-91.7$ & $\begin{array}{l}\text { Clay dark greyish } \\
\text { micaceous calcareous }\end{array}$ & $\begin{array}{l}\text { Ichtyolaria suprajurensis (Mjatliuk), Lenticulina cultrati- } \\
\text { formis Mjatliuk, L. uhligi (Wisniowski), L. pseudocrassa } \\
\text { Mjatliuk, Epistomina mosquensis Uhlig }\end{array}$ \\
\hline $\mathrm{T}_{1}$ Lower Triassic & $91.7-101.2$ & Clay red coloured & \\
\hline
\end{tabular}




\section{ORIGINAL TAXA DESCRIPTION ${ }^{2}$}

Rather recently it was thought that the planktonic foraminifera - mainly Globigerinidae - appeared en masse for the first time during the early Cretaceous (Subbotina, 1953). Rare and often doubtful findings of Globigerinidae in the Jurassic deposits of France and Poland (Terquem, 1876. 1886) already in the 19th century required checking, and they could not affect significantly the understanding of stratigraphic distribution of this family.

However, lately new data began to be accumulated to reveal the geological history of the planktonic Rhizopoda (Foraminifera). At present, the fact of a rather wide distribution of planktonic foraminifera in the Upper Jurassic deposits of the East European (Russian) Platform raises no doubts. Thus, the representatives of Globigerinidae family were detected by L. G. Dain in the Oxfordian of Moldova, Eastern Ukraine, and Russian Ulyanovsk Region (pers. comm. by L. G. Dain). In Lithuania, the planktonic forms (Globigerina oxfordiana sp. n.; further here - Globuligerina oxfordiana (Grigelis)) had been detected by the author of the present article in the argillaceous-silty deposits of the Lower Oxfordian in the south-western land area, where Globuligerina oxfordiana (Grigelis) was observed en masse in separate samples.

The findings of Globigerinidae are also known in the Middle Jurassic of the USSR area. According to V. T. Balakhmatova (1953), the representatives of this family were detected in the Bajocian deposits of Turkmenistan. The doubts expressed by O. K. Kaptarenko-Chernousova (1954) about the reliability of the findings have no grounds, in our opinion.

Nevertheless, the Jurassic representatives of planktonic foraminifera, in particular Globigerinidae, are rather insufficiently studied. The known rare findings of these forms in the Middle and Upper Jurassic deposits of some USSR regions cannot present a full view of the development of species and genera of the Globigerinidae family for that time, but at a certain degree they report about the first appearance and the initial stage of development of the mentioned family - one of the first families of foraminifera, which switched

\footnotetext{
2 Text in Russian, translated by Aloyzas Alius, authorized 04.04.2016
}

to the planktonic mode of life. Globigerina oxfordiana sp. n. was detected in some profiles in south-west Lithuania (Jotija village in Šakiai District, and settlement of Lyduvenai in Tytuvenai District) within the assemblage of foraminifera typical of Lower Oxfordian deposits in Lithuania: Spirophthalmidium birmenstorfense (Kübl. et Zw.), Lenticulina brückmanni (Mjatl.), L. posttumida (Dain), L. comptula (Schwag.), Planularia vaginuliniformis (Paalz.), Vaginulina flabellata Gümb., Trocholina transversarii Paalz., Pseudolamarckina jotijae Grigelis nom. msc., Epistomina volgensis Mjatl., E. intermedia Mjatl., E. bruckmanni Grigelis nom. msc., Epistominoides primaevus Grigelis and other species. These deposits are known to contain Cardioceras tenuicostatum Nik., Cylindrotheutis beamontiana (Orb.) (defined by J. Dalinkevičius) and some other species of fossil molluscs.

\section{Family Globuligerinidae Loeblich et Tappan, 1984}

[Conoglobigerinidae fam. nov. 1997, Simmons et al. in Boudagher-Fadel et al.] Genus Globuligerina Bignot et Guyader, 1971

Originally: Globigerina d'Orbigny, 1826

Globuligerina oxfordiana (Grigelis, 1958)

Originally: Globigerina oxfordiana sp. . $^{3}$

Plate 1, Figs. 1-4, Plate 2, Figs. 1-4, Plate 3, Figs. 1-4, Plate 4, Figs. 1-4

1958 'Globigerina' oxfordiana sp. n., A. Grigelis, Nauchnye Doklady Vysshey Shkholy, Geologo-Geograficheskiye Nauki, No. 3, p. 110-11, text-fig 1.

1966 Globigerina oxfordiana Grigelis, J. Guyader, p. 178, Pl. 28, Fig. $28^{\text {a }}$-c.

1966 Globigerina oxfordiana Grigelis, G. Bignot and J. Guyader, p. 105-107; Plate 1, Figs. 1-11.

1970 Globigerina oxfordiana Grigelis, J. Th. Groiss, S. 74 [no figure]

1971 Globuligerina oxfordiana (Grigelis), G. Bignot and J. Guyader, p. 83; Plate 1, Figs. 1-4; Plate 2, Figs. 3-4.

1980a Globuligerina oxfordiana (Grigelis), A. Grigelis and T. Gorbachik, p. 24, Pl. 1, Fig. 4. 1980b Globuligerina oxfordiana (Grigelis), A. Grigelis and T. Gorbachik, p. 182, Pl. 1, Fig. 4.

\footnotetext{
3 Synonyms are postscript amendment.
} 
1983 Globuligerina oxfordiana (Grigelis), T. H. Gorbachik, p. 48-51, 6 plates.

1985 Globuligerina oxfordiana (Grigelis), A. Grigelis, p. 179, Pl. VIII, Fig. 6, Pl. XXXIX, Fig. 3.

1986 Globuligerina oxfordiana (Grigelis), B. Stam, p. 110-112; Plate 7, Figs. 1-5 (not 6-12); Plate 8, Figs. 4-7, (not 8-12); Plate 9, Figs. 1-5; Plate 14, Figs. 3-4, 8-15 [cited from Simmons et al., 1997].

1986 Globuligerina oxfordiana (Grigelis), R. Wernli and P. Kindler, p. 141, Fig. 3, Pl. Figs. 1-4, 8-10, 12.

1992 Globuligerina oxfordiana (Grigelis),Y. Samson et al., p. 419-420, Pl. IV, Figs. 1-14.

1996 Globuligerina oxfordiana (Grigelis), K. I. Kuznetsova et al., p. 191, Pl. XV, Fig. 24.

1997 Globuligerina oxfordiana (Grigelis), M. Simmons et al. in M. K. Boudagher-Fadel et al., p. 26-27; Plate 1.1, Fig. 1; Plate 1.2, Figs. 1-5; Plate 2.9 , Figs. $1-15$.

1998 Globuligerina oxfordiana (Grigelis), F. T. Banner and D. Dessai, p. 146, Pl. 1, Figs. 1-3. 1999 Globuligerina oxfordiana (Grigelis), A. Grigelis and E. Norling, p. 97, Pl. 5, Figs. 4-8. 1999 Globuligerina oxfordiana (Grigelis), A. Görög and R. Wernli, p. 421-422, Pl. I, Figs. 1-4, 7-10.

2000 Globuligerina oxfordiana (Grigelis), K. I. Kuznetsova, Pl. III, Figs. 11-14. ox 1-2.

2002 Globuligerina oxfordiana (Grigelis),

A. Görög and R. Wernli, p. 28, Pl. I, Figs. 1-27. 2003 Globuligerina oxfordiana (Grigelis), K. I. Kuznetsova et al., p. 55, Pl. V, Figs. 12-14.

The holotype is in the collection at the Department of Geology of Vilnius University; No. 145, Lower Oxfordian, Lithuania, Šakiai District (borehole, Jotija village; depth $143 \mathrm{~m}$ ).

Diagnosis. The shell is trochoidal consisting of a two-whorl spiral, each with four ball-shaped chambers; its primary aperture above the umbilicus is in a shape of a half-moon with a small lip.

Description. The shell is trochoidal, small, and oval in shape with a festoon-like contour. On the dorsal side, there are two whorls of a spiral, each containing four globular chambers, contiguous but not overlapping each other. The first initial whorl on the dorsal side lies slightly above the second or later whorl. As the shell is growing, the chambers are gradually increasing in size. The sutures are linear, straight and deep.
On the ventral side, the chambers of the ultimate whorl are visible. At the centre, there is a small umbilicus. The aperture in a shape of the halfmoon (loop-shaped) at the umbilical margin of the last chamber has a small lip. The wall is porous, roughish and calcareous.

Size, in $\mathbf{m m}$ : max. diameter ranges within $0.17-0.25$, min. diameter is $0.15-0.21$, and height is 0.13 .

Variability. The dorsal (spiral) side of a test of Globuligerina oxfordiana (Grigelis), depending on the degree of trochoidity of a spiral, is varying from a flattened to low-conical shape. The degree of compactness of joints of chambers for the last whorl is also varying. As a rule, the test is formed of incompactly joining contiguous chambers - such specimens are oval in shape; while the shells with more compactly laid chambers in a spiral are of round shape. In both cases, the chambers do not overlap each other by their margins.

Comparative notes. Globuligerina oxfordia$n a$ (Grigelis) resembles slightly the globigerinids described by V. T. Balakhmatova from the Bajocian deposits in the Gaurdak region of Turkmenistan under the name of Globigerina ex gr. bulloides d'Orbigny (1953, p. 87, Fig. 1). The species described differs from the latter ones in a less compact joining of chambers into spirals and more even growth of their sizes on the last whorl. Moreover, the aperture for the forms described by V. T. Balakhmatova is not distinguishable and closed by shell outgrowths and plates, thus significantly differing from G. oxfordiana. The Lower Cretaceous "Globigerina" hoterivica Subbotina and "Globigerina" infracretacea Glaessner differ from Globuligerina oxfordiana (Grigelis) in larger numbers of chambers and whorls as well as smaller shell size.

Distribution and geological age: Lithuania, districts of Šakiai and Tytuvėnai, Lower Oxfordian.

Material. The collection contains about a hundred of well-preserved specimens.

\section{DESCRIPTION OF SEM DATA (PLATES I-IV)}

The scanning laser electronic microscope SEM QUANTA-250 (The Netherlands, 2015) and 

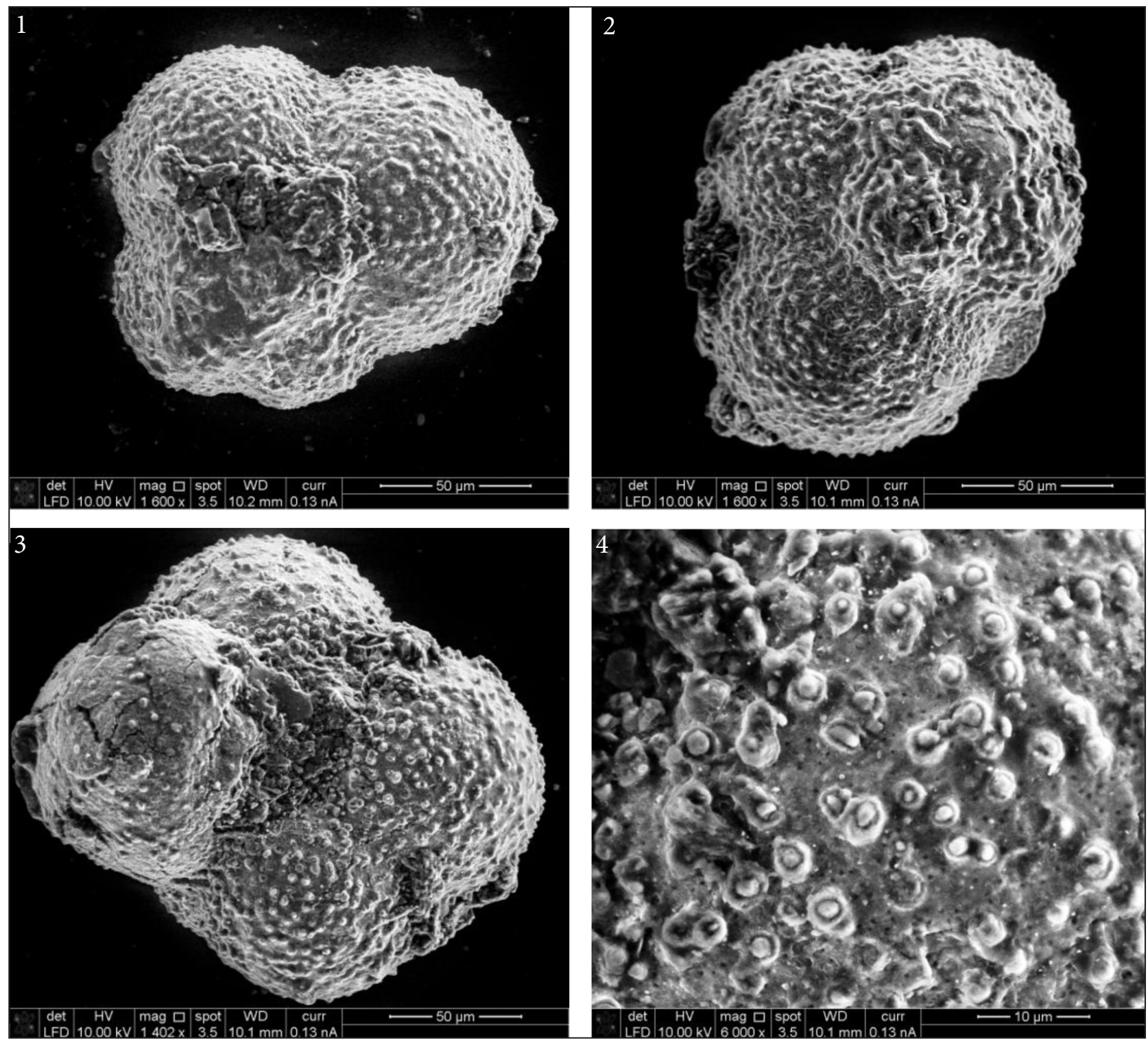

Plate I. Globuligerina oxfordiana (Grigelis, 1958), Figs. 1-4, topotypes, Jotija borehole, $143 \mathrm{~m}$, sample 10. Lower Oxfordian, SW Lithuania. 1. Dorsal view, dextral coiling, pustule wall surface, D - $160 \mu \mathrm{m}$, $\mathrm{d}-133 \mu \mathrm{m}, \times 1600 ; 2$. Dorsal view, sinistral coiling, D $-155 \mu \mathrm{m}, \mathrm{d}-124 \mu \mathrm{m}, \times 1600$; 3. Ventral view, $\mathrm{D}-174 \mu \mathrm{m}, \times 1402 ; 4$. The same specimen, detail of pointed pustule wall surface, pustulae diameter $1-3 \mu \mathrm{m}, \times 6000$.

supplementary devices are installed in the Open Centre of the Nature Research Centre at Akademijos 2, Vilnius, Lithuania, the work is dated March-April 2016. The new model of SEM is based on the laser scanning method; therefore, an object to be studied doesn't need to be covered by golden dust; that is important if it is necessary to save, for example, holotypes of specimens. The specimens of planktonic foraminifera have been taken from A. Grigelis' collection by Dr. Agne Aleksienè, and the scanning photography operator was Dr. Gailè Žalūdienè. Preservation of tests is good or excellent, shells are mainly empty, not filled in by postdiagenetic particles. Magnification scale in $\mu$ is reported on the photo margins. Photography results numbered are stored as TIFF files in SEM Lab archive.

The SEM born micrograph data of exclusively well-preserved specimens confirm in detail all main morphology features of Globuligerina oxfordiana (Grigelis): oval slightly elongate test (D:d $>1$ ) with festoon-like contour, low trochoid spiral $(\mathrm{d}: \mathrm{H}>1)$, round spherical chambers, deep line-like sutures, open umbilicus with a wide mouth of a high 

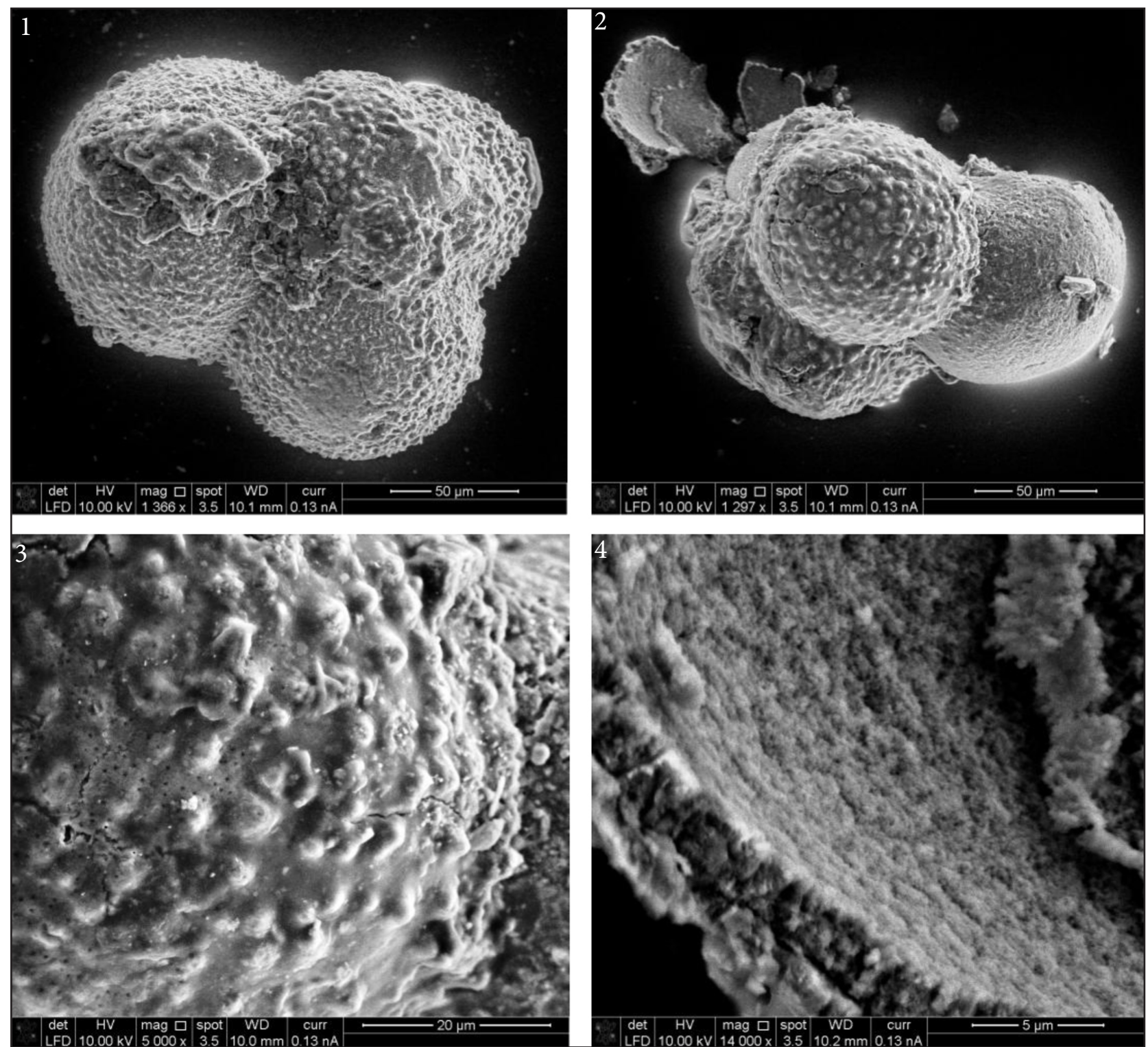

Plate II. Globuligerina oxfordiana (Grigelis, 1958), Figs. 1-4, topotypes, Jotija borehole, $143 \mathrm{~m}$, sample 10. Lower Oxfordian, SW Lithuania. 1. Dorsal view, dextral coiling, pustule wall surface, D - $184 \mu \mathrm{m}$, $\mathrm{d}-140 \mu \mathrm{m}, \times 1366 ; 2$. Peripheral view, $\times 1297 ; 3$. The same specimen, detail of pustule wall surface, rarely joining in short ridges, diameter of pustulae $3-4 \mu \mathrm{m}, \times 5000 ; 4$. The same specimen, details of broken wall the thickness of which exceeds ca. $5 \mu \mathrm{m}$, radial crystals and pores in between are visible in bilamellar wall, $\times 14000$.

arch-like aperture rimed by a well expressed lip, the last bulla-like chamber with a smoother wall surface; a slowly growing spiral contains four chambers, two in each whorl. The wall is microperforate with pores of ca. $1 \mu \mathrm{m}$ in diameter. Wall surface is densely sculptured with a few different modes: (1) by cone-like blunt pustules (pseudomuricae) with a diameter of $1-4 \mu \mathrm{m}$ pointed in the centre by a small raise with a micro-pore, (2) by porous pustules joining into short irregular ridges, (3) by the ridges joining in a reticulate wall pattern having irregular porosity. New observation distinguishes a notable case with the wall surface changes from reticulate to pustule and to rather smooth on the last chamber (Plate IV, Fig. 4). The details of the broken wall show that its thickness does not exceed $5 \mu \mathrm{m}$, pores are visible in the bilamellar wall in between with the radial micro-crystals. According to M. K. Boudagher-Fadel et al. (1997), the wall of Globuligerina oxfordiana (Grigelis) studied by X-ray diffraction is 


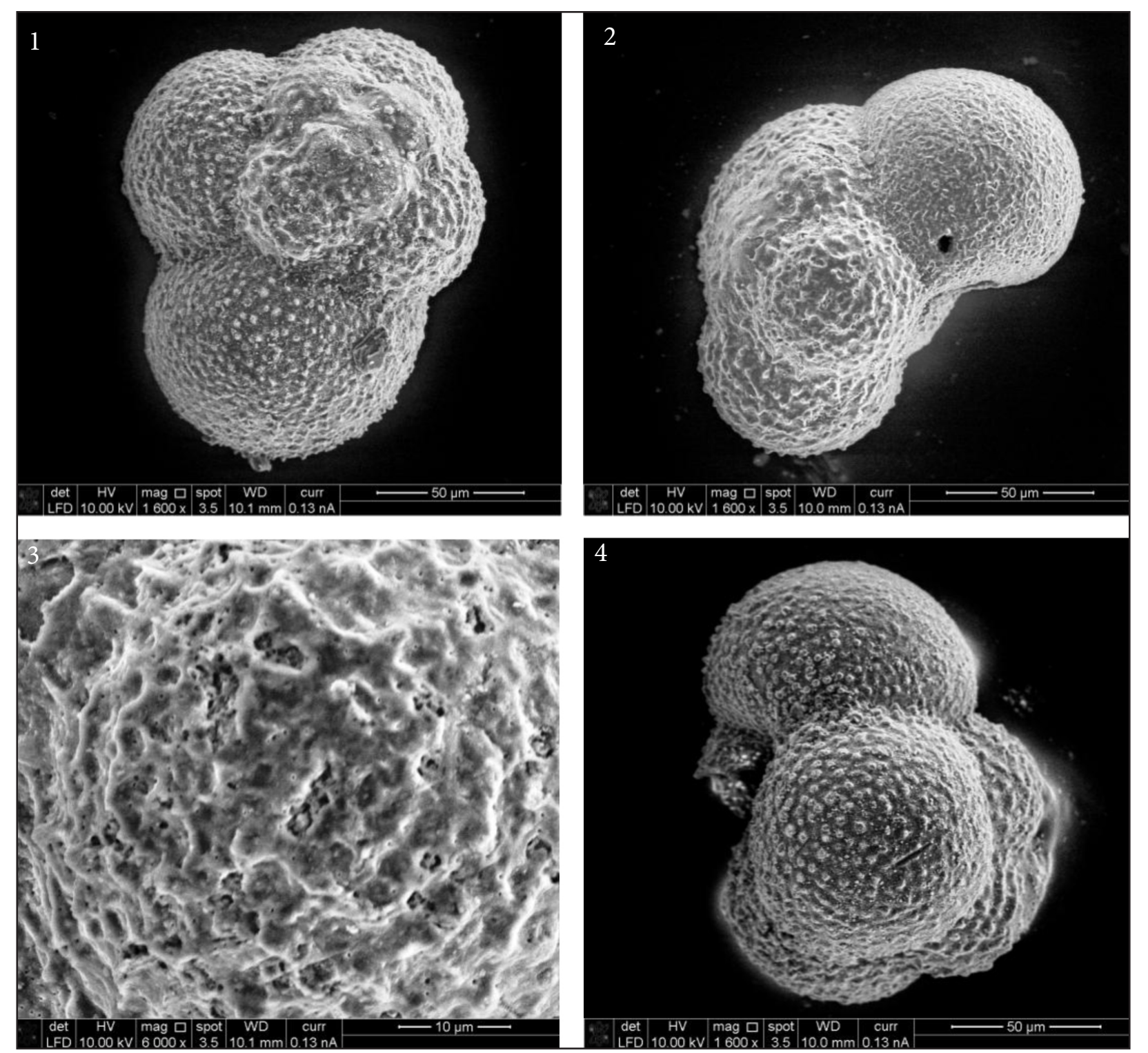

Plate III. Globuligerina oxfordiana (Grigelis, 1958), Figs. 1-4, paratypes, Shatrishche-2, sample 801. Middle to Upper Oxfordian, Rjasan' District, Central Russia. 1. Dorsal view, sinistral coiling, pustule wall surface, $\mathrm{D}-160 \mu \mathrm{m}, \mathrm{d}-124 \mu \mathrm{m}, \times 1600 ; 2$. Peripheral view, bulla-like last chamber, reticulate wall surface, $\mathrm{D}-152 \mu \mathrm{m}, \mathrm{H}-125 \mu \mathrm{m}, \times 1600$; 3 . Detail of reticulate wall surface, $\times 6000 ; 4$. Peripheral view, pustule wall surface, $\times 1600$.

considered to be aragonitic. The micro-crystals are seen on fractured walls (here, Plate II, Fig. 4).

\section{DISCUSSION}

In two decades after the findings made by V. T. Balakhmatova in 1953, the Jurassic planktonic foraminifera were found in the localities along the Parathetys northern margins and received recognition from many authors (Grigelis, 1958; Hofman, 1967; Seibold, Seibold, 1959; Morozova,
Moskalenko, 1961; Jovčeva, Trifonova, 1961; Guyader, 1966; Oesterle, 1968; Pazdrowa, 1969; Groiss, 1970; Bignot, Guyader, 1971; Ascoli, 1976; Gradstein, 1978; etc.). However, some findings were partly questionable and needed approval (especially, described by Fuchs, 1973, 1975). A discussion took place on the Second Roma Planktonic Conference in 1970 where J. Hofker, Senior (1971) expressed an opinion that these are of trochamminid branch (see Bignot and Guyader, 1971). Nevertheless, evidently it became true that this "globigerinae-like" 

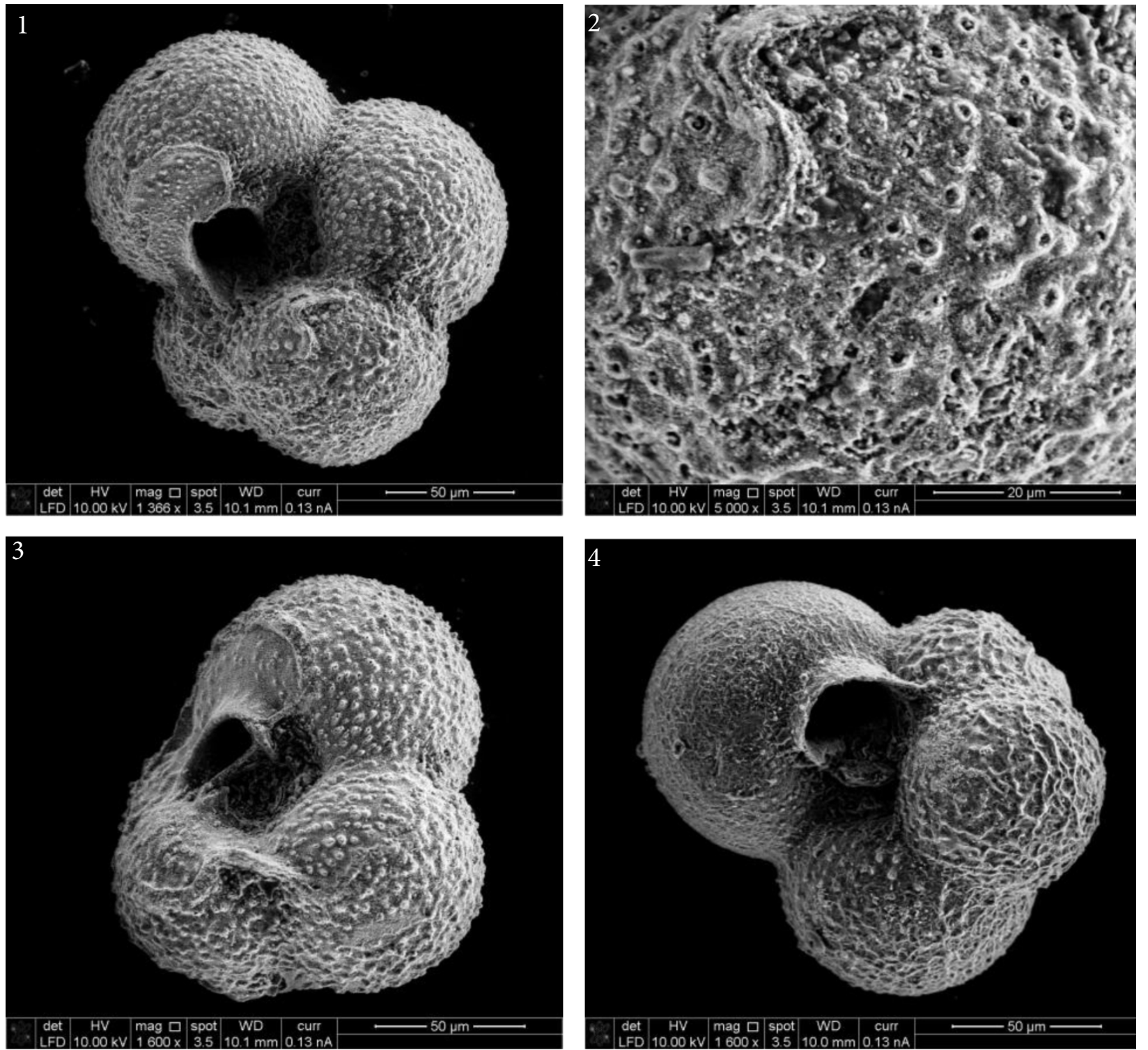

Plate IV. Globuligerina oxfordiana (Grigelis, 1958), Figs. 1-4, paratypes, Shatrishche-2, sample 801. Middle to Upper Oxfordian, Rjasan' District, Central Russia. 1. Ventral view, pustule wall surface, halfmoon mouth with a small lip, $\mathrm{D}-170 \mu \mathrm{m}, \mathrm{d}-140 \mu \mathrm{m} ; \times 1366 ; 2$. Detail of pustule wall surface, $\times 5000$; 3. Slightly oblique ventral view, pustule wall surface, $\mathrm{D}-150 \mu \mathrm{m}, \times 1600 ; 4$. Ventral view, half-moon mouth is rimed by a lip, wall surface changes from reticulate to pustule and to rather smooth on the last chamber, $\mathrm{D}-150 \mu \mathrm{m}, \mathrm{d}-130 \mu \mathrm{m}, \times 1600$.

group often called "primitive globigerine", "protoglobigerine", "pseudoglobigerine" (Colom, 1955) actually presents the earliest phase of evolution of planktonic foraminifera. The time span of the Jurassic period should be taken into account: 203$135 \mathrm{Ma}$; Toarcian base $184 \pm 3 \mathrm{Ma}$ (Ogg, Hinnov, in Gradstein, 2012).

Summarising the recognised data, the author of this article first described the Jurassic stage of development of planktonic foraminifera (Grigelis, 1974). A list of 10 species is presented, and Globu- ligerina Bignot et Guyader, 1971 is first assigned to the genus rank (sensu subgenus Globuligerina of French authors). The following year, an extended paper on the Jurassic stage of the evolution of planktonic foraminifera was published (Grigelis, 1975), where the author stated that this group first appeared in the earliest Jurassic and since mid-early Jurassic began to develop in the Tethys Ocean spreading to its northern Peritethys margins from Turkmenistan and Dagestan to Portugal and to shallow epicontinental seas of the East 
European (Russian) Platform, to North-West Europe hercynian structures and North Atlantic Shelf (Gordon, 1970). After Grigelis (1975), the Jurassic stage of development of planktonic foraminifera is characterised by a relative phyletic isolation, rather low rate of evolution, low individual variability and rather uniform morphology, and small and sporadic populations.

Thus, following Hans M. Bolli (1986) about three major phases of planktonic foraminifera development, i. e. the Cretaceous, Palaeocene-Eocene and Oligocene to Recent, the fourth - actually, first phase should be added - Jurassic (and latest Triassic?). By Bolli, evolutionary criteria are indicated as changes in test size, chamber and test shape, test surface ornamentation, apertures and accessory aperture structures. However, as regards Jurassic planktonic foraminifera, these principal morphological patterns seem only little variables, evolutionary changes not clearly expressed, low biodiversity at species and genera levels; however, phyletic lineages because of rare and incomplete material are still difficult to recognise.

Afterwards, in latest decades a lot of new discoveries of planktonic foraminifera have been reported in different regions from the entire sequence of Jurassic sedimentary basins, showing its worldwide distribution. Globuligerina oxfordiana (Grigelis) has been reported from Oxfordian of Central Russia (Makarievo), France (Normandy), South-West England (Dorset), Portugal, Central Turkey (Ankara region), Central Syria (Palmyrides), Callovian-Oxfordian of Pre-Alps, Middle-Upper Bathonian (Bakony Mts) and Bajocian (Som Hill) of Hungary (Bignot, Janin, 1984; Wernli, Kindler, 1986; Wernli, 1987, 1988; Grigelis et al., 1989; Samson et al., 1992; Ascoli, Grigelis, 1993; Kuznetsova et al., 1999; Görög, Wernli R., 1999, 2002, 2003, 2004, 2010, 2013; Hart et al., 2007; Oxford et al., 2002). The set of Jurassic planktonic foraminifera increases to ca. 20 species and five genera (Korchagin, 2003). However, their systematic and taxonomy is not yet arranged in an acceptable form. In addition, it has been reported about some finds of planktonic foraminifera in the Upper Rhaetian of uppermost Triassic of the Crimea (Korchagin et al., 2003), which should be studied on a more representative sampling material.
Actually, the increasing knowledge sets up more general queries, first at all, as regards the origin and early evolution, biodiversity and biogeography of Jurassic planktonic foraminifera (e. g., Grigelis, 1983; Gorbatchik et al., 1986; Boudagher-Fadel et al., 1997; Kuznetsova, 2000; Hart et al., 2002, 2003; Görög, Wernli, 2003; Hudson et al., 2009; etc.). A hypothetical evolutionary process how benthonic rotaline foraminifera became planktonic habitats by gametogenesis is rather decisively described in biology terms by Simmons et al. (Chapter 2, in Boudagher-Fadel et al., 1997). The first discorbid-like representatives may already have the meroplanktonic mode of life becoming planktonic in the last test whorl stage as some late Bajocian Conoglobigerinae. Certain lineages in the Jurassic succession are discussed by Hart et al. (2002) having studied new field work material of Praegubkinella/Oberhauserella assemblages of the early Toarcian age, i.e. above Toarcian "anoxic event" (see also Hart et al., 2003). The concept of palaeobiogeography of early planktonic foraminifera stated by Hudson et al. (2009) accepts Praegubkinella as an earlier ancestor of Conoglobigerina in the Toarcian. The later evolution and dispersion of planktonic (holoplanktonic) foraminifera floats after the Middle Jurassic into the earliest Oxfordian that marked for the first time a widespread expansion of Globuligerina oxfordia$n a$ (Grigelis) into the World Ocean are most likely related to high stands of sea level and movements of tectonic plates (Hudson et al., 2009).

After the first data of the Jurassic planktonic foraminifera were received, soon it became clear that because of their wide distribution and calibrated stratigraphic value they could be used in biostratigraphy as markers in microfossil zonation (actually important for deep sea drillings). Most likely, P. Ascoli (1976) was the first who reported Globuligerina bathoniana (Pazdro) from the Bathonian and Globuligerina oxfordiana (Grigelis) from the Oxfordian as relative age markers in the microfossil assemblages of the Scotian Shelf, Atlantic Canada. This destination was developed by the established zone foraminifera subdivision for the Jurassic of Eastern Europe (Grigelis, 1980, 1987; Grigelis, 1982, 1983; Grigelis, Kuznetsova, Yakovleva, 1984; Azbel et al., 1986; Grigelis, Kuznetsova, 1987, 1993; Kuznetsova et al., 1991), Sweden (Grigelis, Norling, 1999), and Canada 
Atlantic Shelf (Ascoli, Grigelis, 1993; Grigelis, Ascoli, 1995). Globuligerina oxfordiana is chosen as a zone index-species for Lower Oxfordian marking the chronozone level (peak zone, abundant zone). Actually, the phylozone of this species is wider, if trusted in exact determinations, from possibly the Late Bajocian to the Kimmeridgian (Grigelis, 1980).

\section{CONCLUSIONS}

The Jurassic planktonic foraminifera is a widely distributed "globigerine-like" group that actually presents an earliest phase of their evolution. The group first appeared in the earliest Jurassic and since mid-early Jurassic began to develop in the Tethys Ocean spreading to its northern Peritethys margins. The Jurassic stage of development of planktonic foraminifera is characterised by relative phyletic isolation, rather low rate of evolution, low individual variability and rather uniform morphology, and small and sporadic populations. The dispersion of planktonic (holoplanktonic) foraminifera floats after the Middle Jurassic into the earliest Oxfordian, which marked for the first time a widespread expansion of Globuligerina oxfordiana (Grigelis) into the World Ocean, is most likely related to high stands of sea level and movement of tectonic plates.

The revision and re-description of the Globuligerina oxfordiana (Grigelis, 1958) presents an extended study of topotypes of this species by means of a modern laser scanning microscopy technique (SEM). After the first publications, the SEM born micrograph data of exclusively well-preserved specimens confirm in detail all main morphology features of this taxon.

The Jurassic planktonic foraminifera, because of their wide distribution and calibrated stratigraphic value, are already used in biostratigraphy as markers in microfossil zonation. This destination has been developed by the established zone foraminifera subdivision for the Jurassic of Eastern Europe, Sweden, and Canada Atlantic Shelf.

\section{ACKNOWLEDGEMENTS}

The author is grateful to Professor Felix Gradstein (Oslo) who initiated interesting work on the Atlas of Jurassic Planktonic Foraminifera and, indirect- ly, stimulated elaboration of this paper. Dr. Agnè Venckutè-Aleksienè and Dr. Gailè Žalūdienè (Nature Research Centre, Vilnius) are appreciated very much for their valuable assistance with SEM micrographs. The reviewers of the paper are thanked for useful comments and suggestions.

Received 1 May 2016 Accepted 16 June 2016

\section{References}

1. Ascoli P. 1976. Foraminiferal and ostracod biostratigraphy of the Mesozoic-Cenozoic Scotian Shelf, Atlantic Canada. First International Symposium on Benthic Foraminifera of Continental Margins. part B. 653-771.

2. Ascoli P., Grigelis A. 1993. Zonal subdivision of Middle Jurassic-Early Cretaceous of Canada and Eastern Europe according to foraminifera. Stratigrafiya. Geologicheskaya korrelatsiya. Moskva. 1(4): 47-55 [in Russian].

3. Azbel A. Ya., Grigelis A., Kuznetsova K. I., Yakovleva S. P. 1986. Zonal assemblages of Upper Jurassic foraminifers of the East-European Plate. In: Jurskiye otlozheniya Russkoi platformy. Leningrad. 155-172 [in Russian].

4. Balakhmatova V. T. 1953. On Middle Jurassic Globigerinidae and Globorotaliidae. In: Palaeontology and Stratigraphy, Proceedings of All-Union Geological Institute. Leningrad [in Russian].

5. Baltrūnas V. (ed.) et al. 2004. Evolution of Earth Crust and Its Resources in Lithuania. Geologijos ir geografijos institutas ir Vilniaus universitetas. Vilnius. 700 p., 211 maps in CD [in Lithuanian; Lietuvos žemès gelmių raida ir ištekliai].

6. Banner F. T., Desai D. 1988. A review and revision of the Jurassic-Early Creteaceous Globigerinina, with especial reference to the Aptian assemblages of Speeton (North Yorkshire, England). Journal Micropalaeontology. 7(2): 143-185.

7. Bignot G., Guyader J. 1966. Découverte de foraminifères planctoniques dans l'Oxfordien du Havre (Seine-Maritime). Revue Micropaléontologie. 9(2): 104-110.

8. Bignot G., Guyader J. 1971. Observations nouvelles sur Globigerina oxfordiana Grigelis. Reprinted from: A. Farinacci (ed.) Proceedings of the II Planktonic Conference in Rome 1970. Rome. 79-83.

9. Bignot G., Janin M.-C. 1984. Découverte de Globuligerina oxfordiana (Foraminifère planctonique) dans le Bajocien stratotypique de la Falaise des Hatchettes (Sainte-Honorine-des Pertes, Calvados, France). Comptes Rendus Académie des Sciences. Paris. 298 II(17): 751-756.

10. Bolli H. 1986. Evolutionary trends in planktic foraminifera from Early Cretaceous to Recent, with 
special emphasis on selected Tertiary lineages. Bulletin Centres Rech. Explor. Prod. Elf-Acquitane. 10(2). 565-577.

11. Boudagher-Fadel M. K., Banner F. T., Whittaker J. E. (with a contribution by M. D. Simmons), 1997. The Early Evolutionary History of Planktonic Foraminifera. London: Chapman \& Hall. 269 p.

12. Colom G. 1955. Jurassic-Cretaceous pelagic sediments of the western Mediterranean zone and the Atlantic area. Micropaleontology. 1(2): 109-124.

13. Fuchs W. 1973. Ein Beitrag zur Kentniss der Jura "Globigerinen" und verwandter Formen an Hand polnischen Materials des Callovien and Oxfordien. Verhandlungen der geologischen Bundesanstalt. 3: 445-487.

14. Fuchs W. 1975. Zur Stammergeschichte der Planktonforaminiferen und verwandten Formen in Mesozoikum. Jahrbuch der geologischen Bundesanstalt. 118: 193-246.

15. Guyader J. 1966. Le Jurassique supérieur de la baie de la Seine - Etude stratigraphique et micropaléontologique. I - Texte, II - Planches. Docteur Thèses de l'Universite de Paris. 269 p., 34 pl.

16. Gorbachik T. N. 1983. Globuligerina oxfordiana (Grigelis) - a typical species of the genus Globuligerina in electron microscope. AN SSSR. 26: 48-51 [in Russian].

17. Gorbachik T. N., Grigelis A. 1982. Significance of planktonic foraminifera for stratigraphy of Jurassic and Lower Cretaceous. In: Biostratigrafiya verchnejurskich otlozheniy SSSR po foraminiferam. Vilnius. 18-21.

18. Gorbatchik T. N., Grigelis A., Kuznetsova K. I. 1986. The earliest stage of development of planktonic foraminifera (Jurassic-Early Cretaceous). In: Main Events in Biota History of the Earth. Vsesoyuznoe Paleontologicheskoye obshchestvo (27-30 January 1986). Tallinn. 27-28 [in Russian].

19. Gorbachik T. N., Kuznetsova K. I. 1997. The changeability of Globuligerina oxfordiana (Grigelis) - type species of genus Globuligerina (Foraminifera and its distribution in the Jurassic deposits. Paleontologicheskiy zhurnal. Moskva. 5: 3-10.

20. Gorbachik T. N., Kuznetsova K. I. 1998. Problems on systematics and nomenclature of the early planktonic foraminifera. Paleontologicheskiy zhurnal. 6: 3-11 [in Russian].

21. Gordon W. A. 1970. Biogeography of Jurassic foraminifera. Bulletin of the Geological Society of America. 81.

22. Gradstein F. M. 1978. Jurassuc Grand Banks foraminifera. Journal of Foraminiferal Research. 8: 97-109.

23. Gradstein F. M. 1998. Review: the early evolutionary history of planktonic foraminifera by M. K. Boudagher-Fadel, E. T. Banner and J. E. Whittaker (with a contribution by M. D. Simmons). Micropaleontology. 44(2): 207-208.
24. Grigelis A. 1958. Globigerina oxfordiana sp. n. - discovery of the first planktonic foraminifera in the Upper Jurassic of Lithuania. Nauchnye doklady Vys'shey shkoly, seriya geologo-geograficheskich nauk. Moskva. No. 3: 109-111 [in Russian].

25. Grigelis A. 1974. On the Jurassic stage of development of planktonic foraminifera. Doklady Akademii nauk SSSR. Moskva. 219(5), 1203-1205 [in Russian].

26. Grigelis A. 1975. Jurassic stage of the development of planktonic foraminifera. Trudy Instituta geologii i geofiziki Sibirskogo otdeleniya AN SSSR. vypusk 333: 56-62 [in Russian].

27. Grigelis A. 1980. Foraminiferal zonation and correlation of the Upper Jurassic of Boreal realm. Rèsumès 26 $6^{e}$ Congrès Gèologique International. Paris. 1: 234.

28. Grigelis A. 1980. Chronozones and phylozones - their nature, similarity and distinction (based on data of Jurassic and Cretaceous foraminifera). Izvestiya Akademii nauk SSSR, seriya geologicheskaya. Moskva. 4: 57-67.

29. Grigelis A. 1983. Jurassic foraminiferal zones of the Boreal Realm and significance of zoogeography for their correlation. In: Mezozoy Sovetskoi Arktiki, Novosibirsk. Trudy Instituta Geologii i geofiziki SO AN SSSR. 555: 95-103.

30. Grigelis A. 1985a. Jurassic Foraminifera of the South-Western Baltic Area. Vilnius: Mokslas. 240 p. [in Russian].

31. Grigelis A. 1985b. Zonal Stratigraphy of the Baltic Jurassic by Foraminifera. Lithuanian Geological Institute. Vilnius. Moskva: Nedra. 131 p. [in Russian].

32. Grigelis A. 1987. New data on the stratigraphic subdivision of the Jurassic by means of foraminifers in the Baltic area and East European platform. Newsletter of the International Subcommission on Jurassic Stratigraphy (ISJS). Oxford. 16, Encl. No. 3: $1-18$.

33. Grigelis A. 2011. Research of the bedrock geology of the Central Baltic Sea. Baltica. 24(1): 1-12.

34. Grigelis A., Ascoli P. 1995. Middle Jurassic-Early Cretaceous Foraminiferal Zonation and Paleoecology of Offshore Eastern Canada and the East European Platform. Geological Survey of Canada Atlantic [Ottawa, Ont.]. Open File No. 3099, 16 p.

35. Grigelis A. et al. 1992. Early Jurassic, Middle Jurassic, Late Jurassic - North and Baltic Seas. In: M. N. Alekseev (ed.). Palaeogeographic Atlas of the Shelf Regions of Eurasia for the Mesozoic and Cenozoic. The Robertson Group plc. and The Geological Institute of the Academy of Sciences of USSR. Llandudno. sheets 11.1, 11.2.

36. Grigelis A., Gorbatchik T. 1980a. On systematics, morphology and taxonomy of Jurassic and Early Cretaceous Globigerinacea. Paleontologicheskiy zhurnal. Moskva. 1: 20-30 [in Russian]. 
37. Grigelis A., Gorbatchik T. 1980b. Morphology and taxonomy of Jurassic and Early Cretaceous representatives of the superfamily Globigerinacea (Favusellidae). Journal of Foraminiferal Research. Washington. 10(3): 180-190.

38. Grigelis A., Jarmakani E., Kuznetsova K., Hallaq L., al Bittar M. 1989. The appearance of Upper Jurassic deposits in Palmyrides. The Syrian Journal of Geology. Damascus. 14: 22-25 [in Arabic, with English summary].

39. Grigelis A. 2007. Geology of Lithuania (Lietuva). In: E. M. O. Sigmond (ed.). Geology of the Land and Sea Areas of Northern Europe: A collection of short descriptions of the geology of countries and sea areas within the region covered by the 1:4 million bedrock geological map. Geological Survey of Norway. Special Publication 10. Trondheim. 51-55.

40. Grigelis A. 2002. In: E. M. O. Sigmond (ed.). Geological Map: Land and Sea Areas of Northern Europe. Scale 1:4 000 000. Geological Survey of Norway. Trondheim. 1 map.

41. Grigelis A., Kadūnas V. (eds.). 1994. The Geology of Lithuania. A Monograph. Vilnius: Mokslo ir enciklopedijų leidykla. 447 p. [in Lithuanian: Lietuvos geologija].

42. Grigelis A., Kuznetsova K. I. 1987. Upper Jurassic stratigraphy chart of the SSSR according to foraminifera. Izvestiya Akademii nauk SSSR, seriya geologicheskaya Moskva. 5: 26-37 [in Russian].

43. Grigelis A., Kuznetsova K. I. 1993. Stratigraphic correlation for the Jurassic by means of foraminifera. Geologija. 14: 146-151.

44. Grigelis A., Kuznetsova K. I., Yakovleva S. P. 1984. Foraminiferal biostratigraphical scale of the Upper Jurassic. 27th Mezhdunarodniy Geologicheskiy Congress, SSSR. 4-14 avgusta 1984. Moskva. 8: 360-361.

45. Grigelis A. A., Mesezhnikov M. S., Yakovleva S. P., Kozlova G. E., 1977. First discoveries of planktonic Foraminifera in the Upper Jurassic deposits of the Pechora River Basin. Doklady Akademii Nauk SSSR. Moskva. 233(5): 926-927 [in Russian].

46. Grigelis A., Norling E. 1999. Jurassic Geology and Foraminiferal Faunas in the NW Part of the East European Platform: a Lithuanian-Swedish geotraverse study. Uppsala. 101 p. (Sveriges Geologiska Undersökning (SGU). Series Ca, Research Papers 89).

47. Grigelis A., Norling E. 2000. Jurassic geology and foraminiferal faunas in the NW part of the East European Platform: a Lithuanian-Swedish geotraverse $s t u d y$. Newsletter of the European Palaeontological Association. 16: 54.

48. Görög A., Wernli R. 1999. Protoglobigerinids (Foraminifera) acid extracted from Bajocian limestones (Hungary). Revista Española de Micropaleonologia. 31(3): 419-426.

49. Görög A., Wernli R. 2002. The Middle and Late Bathonian protoglobigerinids of Gyenespuszta
(Bakony Mts., Hungary). Revue Paléobiologique. Geneve. 21(1): 21-34.

50. Görög A., Wernli R. 2003. Palaeobiogeography of the Middle Jurassic protoglobigerinids (Foraminifera). Eclogae Geologica Helvetiae. 96: 237-248.

51. Görög A., Wernli R. 2004. A rare protoglobigerinid association (Foraminifera) from the Tihonian of Geresce Mts, Hungary. Hantkenina. 4: 37-45.

52. Görög A., Wernli R. 2010. Kimmeridgian protoglobigerinids (Foraminifera) from Crussol (SE France). Swiss Journal on Geoscience. 103: 83-100.

53. Görög A., Wernli R. 2013. Protoglobigerinids of the Early Kimmeridgian of the Jura Mountains (France). Journal of Foraminiferal Research. 43(3): 280-290.

54. Groiss J. Th. 1970. Feinstratigraphische, ökologische und zoogeographische Untersuchungen der Foraminiferen-Faunen im Oxford der Franken Alb. Erlanger geologische Abhandlungen. H. 81, 83 S.

55. Guyader J. 1966. Le Jurassique supérieur de la baie de la Seine - Etude stratigraphique et micropaléontologique. I- Texte, II - Planches. Docteur Thèses de l'Universite de Paris. 269 p. 34 pl.

56. Hart M. B., Aze T., Hudson W., Smart C. W. 2007. Planktic foraminifera from the proposed GSSP for the Oxfordian Stage: Redcliff Point, near Weymouth. Geoscience in South-West England. 11: 273-279.

57. Hart M. B., Hylton D., Oxford M. J., Price G. D., Hudson W., Smart C. W. 2003. The search for the origin of the planktic Foraminifera. Journal of the Geological Society London. 160: 341-343.

58. Hart M. B., Oxford M. J., Hudson W. 2002. The early evolution and palaeobiogeography of Mesozoic planktonic foraminifera. In: Palaeobiogeography and Biodiversity Change: The Ordovician and Mesozoic-Cenozoic Radiations. Geological Society London. Spec. Publ. 194: 115-125.

59. Hudson M., Hart M. B., Smart C. W. 2009. Palaeobiogeography of early planktonic foraminifera. Bulletin de la Société Géologique de France. Paris. 180(1): 27-38.

60. Jovčeva P., Trifonova E. 1961. Tithonian Globigerina from northwest Bulgaria. Proceedings Geological Society Bulgaria, Paleontol. Ser. 3: 343-351.

61. Hofman E. A. 1967. Jurassic Foraminifera of the Northern Caucasus. Moskva: Nauka. 167 p.

62. Kaptarenko-Chernousova O. K. 1954. About the article by V. T. Balakhmatova About Middle Jurassic Globigerinidae and Globorotaliidae. Geologichniy Zhournal. 14(4) [in Ukrainian].

63. Korchagin O. A. 2003. Classification of Mesozoic Planktonic Foraminifera (Superfamilies Planomalinacea, Rotaliporacea and Globotruncanacea). Moscow: GEOS. 88 p.

64. Korchagin O. A., Kutznetsova K. I., Bragin N. Yu. 2003. Finds of early planktonic foraminifera in 
the Triassic of the Crimea. Doklady Akademii Nauk, Geologiya. 390(1): 79-84.

65. Kuznetsova K. I. 2000. Peculiarities of foraminiferal assemblages composition and distribution in the Eastern Mediterranean Jurassic basins. In: I. Panayides, C. Xenophontos and J. Malpas (eds.). Proceedings of the Third International Conference on the Geology of the Eastern Mediterranean. 318-325.

66. Kuznetsova K. I., Bragin I. Ju., Voznesensky A. I., Tekin U. K. 1999. Planktonic and benthic cosmopolitan assemblages of Jurassic foraminifera of Central Turkey. Stratigrafiya. Geologicheskaya korrelyatsiya. 11(5): 40-57 [in Russian].

67. Kuznetsova K. I., Grigelis A., Adjamian J., Hallaq L. 1991. Zonal subdivision of Jurassic deposits in Syria by means of Foraminifera. Izvestiya Akademii nauk SSSR, seriya geologicheskaya. Moskva. 10: 125-127 [in Russian].

68. Kuznetsova K. I., Grigelis A., Adjamian J., Jarmakani E., Hallaq L. 1996. Zonal Stratigraphy and Foraminifera of the Tethyan Jurassic (Eastern Mediterranean). Amsterdam: Gordon \& Breach Science Publishers. 256 p. XXII plates.

69. Loeblich A. R. Jr., Tappan H. 1984. Suprageneric classification of Foraminiferida (Protozoa). Micropaleontology. 30: 1-70.

70. Morozova V. G., Moskalenko T. A. 1961. Planktonic foraminifera of Bajocian and Bathonian of Central Daghestan (North-Eastern Caucasus). Voprosy Mikropaleontologii. Moskva. Vypusk. 5: 3-30.

71. Ogg J. G., Hinnov L. A. 2012. Jurassic. In: F. M. Gradstein et al. (eds.). The Geologic Time Scale. (2): 732-791.

72. Oesterle H. 1968. Foraminiferen der Typlokalitat der Birmenstorfer-Schichten, unterer Malm. Eclogae Geologica Helvetiae. 61(2): 695-792.

73. Oxford M. J., Gregory F. J., Hart M. B., Henderson A. S., Simmons M. D., Watkinson M. P. 2002. Jurassic planktonic foraminifera from the United Kingdom. Terra Nova. 14: 205-209.

74. Pazdrowa O. 1969. Bathonian Globigerina of Poland. Rocznik Polskiego Towarzystwa Geologicznego. 39(1-3): 41-56.

75. Rotkytè L. 1987. Ammonites and Zonal Stratigraphy of the Upper Jurassic of the Eastern Baltic. Vilnius: Mokslas. 119 p. [in Russian].

76. Samson Y., Janin M-C., Bignot G., Guyader J., Breton G. 1992. Les globuligerines (foraminiferes planctoniques) de L'Oxfordien inferieur de Villerssur-Mer (Calvados, France) dans leur gisement. Revue Paléobiologie. 11(2): 409-431.

77. Seibold E., Seibold I. 1959. Über Funde von Globigerinen an der Dogger/Malm Grenze Süddeutschlands. International Geological Congress, Reports 21th Session Norden. Part. 6: 64-68.
78. Subbotina H. H. 1953. Globigerinidae, Hantkeninidae and Globorotaliidae. Proceedings of Oil Prospecting Geological Institute. 76 [in Russian].

79. Suveizdis P. 2003. Tectonic Structure of Lithuania. Institute of Geology and Geography. Vilnius. $60 \mathrm{p}$.

80. Terquem O. 1876. Recherches sur les Foraminiféres du Bajocien de la Moselle. Mémoire de la Société Géologique de France. sér. 3, t. 4.

81. Terquem O. 1886. Les Foraminiféres et les Ostracodes du Fuller's Earth (Zone à Ammonites parkinsoni) des environs de Varsovie. Mémoire de la Société Géologique de France. sér. 3, t. 4, mém. 2.

82. Terquem O., Berthelin G. 1875. Etude microscopique des marnes du Lias moyen d'Essey-lèsNancy, zone inférieure de l'assise à Ammonites margaritatus. Mémoire Societe Géologique France. mém. 2. 10(3): 11-20.

83. Šimkevičius P., Ahlberg A., Grigelis A. 2003. Jurassic smectite and kaolinite trends of the East European Platform: implications for palaeobathymetry and paleoclimate. Terra Nova. Oxford. 15(4): 225-229.

84. Wernli R., Kindler P. 1986. Les "Protoglobigérines" du Callovo-Oxfordien de Châtillom-sur-Cluses (Préalpes internes, Haute-Savoie, France. Eclogae Geologica Helvetiae. 79: 137-147.

85. Wernli R. 1987.Les protoglobigerines (Foraminifers) du Bajocien inferieur des sofs (Rif, Maroc). Eclogae Geologica Helvetiae. 80(3): 817-829.

86. Wernli R. 1988. Les protoglobigerines (foraminifers) du Toarcien et de L'Aalenien du Domuz Dag (Taurus Occidental, Turquuie). Eclogae Geologica Helvetiae. 81(3): 661-668.

\section{Algimantas Grigelis \\ GLOBULIGERINA OXFORDIANA (GRIGELIS, 1958) - PIRMŲJŲ PLANKTONINIŲ FORAMINIFERŲ, RASTŲ LIETUVOS VIRŠUTINĖJE JUROJE, REVIZIJA}

Santrauka

Straipsnyje pateikiama pirmujų planktoninių foraminiferų Globuligerina oxfordiana (Grigelis, 1958), rastų Lietuvos vèlyvosios juros laikotarpio nuogulose, revizija ir atnaujintas aprašymas. Originalus straipsnis, $1958 \mathrm{~m}$. paskelbtas rusų kalba mokslinès periodikos žurnale (Maskva), skelbiamas anglų kalba, papildytas naujais autoriaus duomenimis ir lazerinio elektroninio mikroskopo nuotraukomis.

Raktažodžiai: planktoniniai foraminiferai, juros periodas, Globuligerina 


\section{Appendix}

НАУчНЫЕ ДОКЛАДЫ ВЫСШЕИ ШКОЛЫ

1958 ГЕОЛОГО-ГЕОГРАФИЧЕСКИЕ НАУКИ

\section{GLOBIGERINA OXFORDIANA SP. N.- НАХОДКА Г.ТОБИГЕРИН В ВЕРХНЕЮРСКИХ ОТЛОЖЕНИЯХ ЛИТВЫ}

\section{А. А. Григелис}

Еще в недавнее время считалось, что пелагические фораминиферы - главным образом, семейство Globigerinidae - впервые в массовом количестве появились в нижнемеловую эпоху (3). Известные еще в прошлом столетии редкие и отчасти сомнительные находки глобигеринид в юрских отложениях Франции и Польши $(4,5)$ требовали проверки и не могли существенно менять представления о стратиграфическом распространении этого семейства.

Однако в последние годы стали накапливаться новые сведения, полнее раскрывающие геологическую историю корненожек, ведущих планктонный образ жизни. В настоящее время факт довольно широкого распространения пелагических фораминифер в верхнеюрских отложениях Русской платформы является несомненным. Так, представители сем. Globigerinidae обнаружены Л. Г. Даин в оксфорде Молдавии, восточной Украины, Ульяновской области (устное сообщение Л. Г. Даин). В Литовской CCP планктонные формы (Globigerina oxfordiana sp. n.) найдены автором на юго-западе республики в глинисто-алевритовых тородах нажнеоксфордского возраста. Здесь GIobìgerina oxfordìпа в отдельных образцах встречена в массовом количестве экземпляров.

Находки глюбигериницд известны и в средней юре СССР. По данным В. Т. Балахматовой (1), представители этого семейства обнаружены в байосских отложениях Туркмении. Сомнения О. К. Каптаренко-Черноусовой по поводу достоверности этих находок (2) не имеют, на наш взгляд, достаточных оспований.

Все же юрские представители пелагических фораминифер, в чистности, семейства Globigerinidae, изучены пока в очень малюй степени. Известные немногочисленные находки этих форм в средне- и в верхнеюрских отложениях некоторых районов СССР не могут дать полной картины развития видов и родов сем. Globigerinidae в это время, но в какой-то мере освещают вопрюс о первом пюявлении и началыном этапе развития вышеназванного семейства - одного из первых семейспв фораминифер, перешедших к планктонному образу жизни. Globigerina oxfordiana sp. n. обнаружена в нескольких разрезах юго-запада Литвы (с. Котия Шакяйского района, мест. Лидувенай Титувенскопо района) в комплексе фораминифер, характерном для нижнеоксфордских отложений Литовской ССP: Spirophthalmidium birmenstorfense (Kübl. et Zw.), Lenticulina brückmanni (Mjatl.), L. posttumida (Dain), L. comptula 
(Schwag) Planularia vaginuliniformis (Paalz.), Vagínulina flabellata Gümb., Trocholina transversarii Paalz., Pseudolamarckina jotijae Grigelis nomr msc., Epistomina volgensìs Mjatl., E. intermedia Mjatl., E. brückmanni Grigelìs nom., msc., Epistomínoides primaevus Grigelis и другие виды. В этих же отложениях известны Cardioceras tenuìcostatum Nik., CyIindrotheutis beaumontiana (Orb.) (определения И. Далинкевичюса) и некоторые другие виды ископаемых моллюсков.

Род Globigerina Orbigny, 1826.

Globigerina oxfordiana sp. n.

Голопип в коллекции кафедры геологии Вильнюсскопо посударспвенного университета им. В. Капсукаса за № 147; нижнеоксфордский подъярус, Литювская ССР; Шакяйский район (с. Нотия).

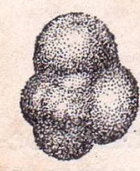

$a$

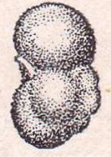

$\delta$

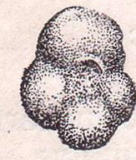

B

Ди агно з. Раковина трохоидная из двух оборотов спирали, в каждом обороте по 4 шаровидных камеры; устье над пупком в виде полулунного отверстия с маленькой губой.

Опи с а ние. Раковина трохоидная, маленыкая, овальная в очертании, с фестончатым контуром. Со спинной стороны видны два оборота спирали, в каждом из которых содержится по 4 шаровидных, прилегающих одна к другой, но не перекрывающихся камеры. Первый, ранний оборот на спинной стороне несколько возвышается над вторым, поздним. Камеры по мере рюста раковины увеличиваются постепенню. Швы линейные, прямые, глубокие. На брюшнюй стороне видны камеры последнего оборота. В центре здесь имеется небольшой пупок. Устье в виде полулунного отверстия у пупочнюго края последней камеры, снабженное маленыкой губой. Стенка пористая, шероховатая, известковая.

Размеры в мм: наибольший диаметр 0,17-0,25; наименьший диаметр $0,15-0,21$; высота 0,13 .

И зм е н чи в ость. У Globigerina oxfordiana sp. n., в зависимости от степени трохоидности спирали, спинная сторона раиквины изменяется от уплоценной до низкоконической. Варьирует также степень компактности соединения камер последнего оборота. Обычно раковина образова-

на неплотно соединениыми, прилегающими камерами, - такие экземпляры имеют овальную форму; раковины же с более плотным расположением камер в спирали нмеют округлую форму. В обоих случаях камеры не прекрываются между собой своими краями.

Ср а внительные з а мечания. Globigerina oxfordiana sp. $п$. несколько напоминает глюбигерин, описанных В. Т. Балахматовой из байосских отложений Гаурдакского района Туркменской ССР под названием Globigerina ex gr. bulloides Orbigny (1, стр. 87 , рис. 1). От последних форм описываемый вид отличается мменее плотным соединением камер в спирали и более равномерным ростом их размеров в последнем обороте. Қроме пого, устье у описанных В. Т. Балахматовой форм неразличимо и закрыто раковинными выростами и пластинками, чтю существенно отличает их от G. oxfordiana. Нижнемеловые Globigerina hote-

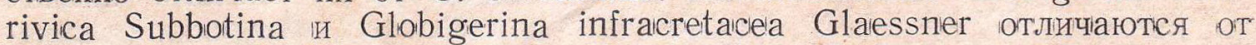
Globigerina oxfordiana sp. n. большим количеством камер и юборотов и меньшими размерами раковины.

110 
Р аспространенле и геолотический возраст: Литовская ССР, Шакяйский и Титувенский районы, нижний оксфорд.

Материал. В коллекцли имеется около ста экземпляров хорошей сохранности.

\section{ЛИ Т Е Р А Т У Р А}

1. Б а л ах м а тов а В. Т. О среднеюрских Globigerinidae и Globorotaliidae. В сб. «Палеонтология и стратиграфия». Тр. Всесоюзн. н.-и геол. ин-та, 1953.

2. К апт а ренко-Ч ер н усов О. К. 3 приводу статті В. Т. Балахматовоі «Про середньорскі Globigeriridae, $i$ Globorotalidae». Геологічний журнал, т. 14 ,
вып. 4, 1954.

3. С у бб о ти н а Н. Н. Глобигерднды, ханткениниды и глобороталииды. Тр. Всенефт. н.-и. геол. разв. ин-та, нов. серия, вын. 76,1953

4. T e rquem $\mathrm{O}$. Recherches sur les Foraminiféres du Bajocien de la Móselle. Bull. Soc. Géol. France, sér. 3, t. - 4, 1876.

5. T er quem O. Les Foraminiléres et les Ostracodes du Fuller's Earth (Zone à Ammonites parkinsoni) des environs de Varsovie. Mém. Soc. Géol. France, sér. 3,
t. 4, mém. 2, 1886.

Вильнюсский университет, факультет естественных наук, кафедра геологии
Поступила в редакцию 30 декабря 1957 г. 